
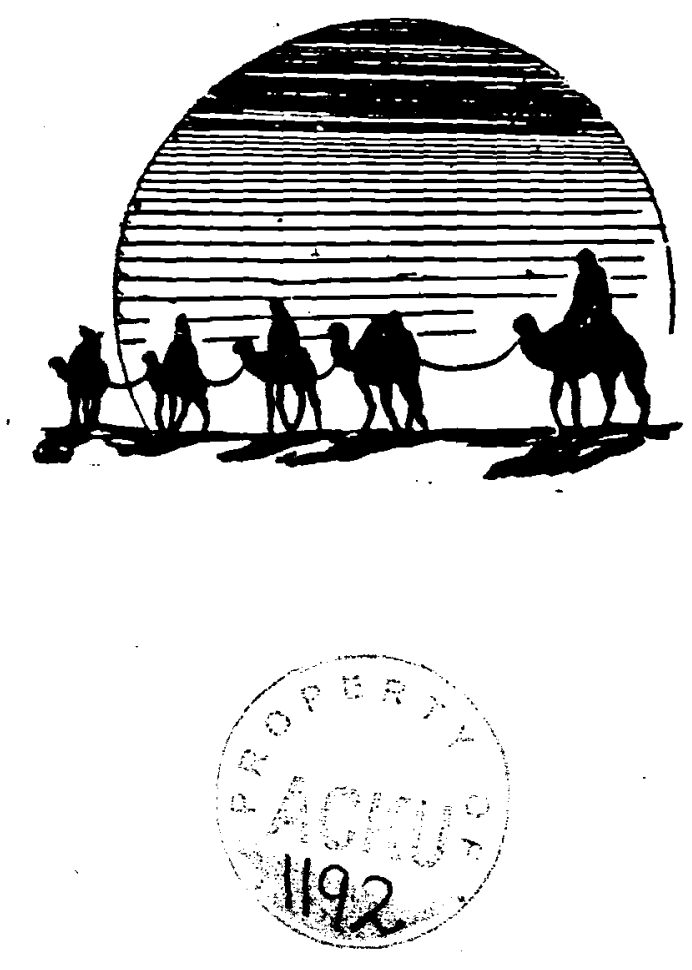
By A. Kayeum Qauim

\section{Translated by A. W. \\ THE DARI FOLK SPEECH IN TAKHAR}

ie story of Dari recorded lit?re is a long one. There are and a variety of poems on lus topics in this langnage, " the era of Poshang Kings of it who were contemporary Tahir, the son of Hussein. to modern times; some of the s having been outstanding in $r$ own ways. The poets in this tongue have had composed ificent pieces at various tiand places on different subhaving something to do with or the other aspect of their ty. The history of literature zuaranteed the value of their is and the literary taste of thwho speak Dari adores the $y$ of their products.

e Dari recorded literature has described comprehensively to $r$ all eras. However, nothing jeen done so far to introduce - speech", as defined by Sir ye Laurence Gomme in his Idbook of Folklore" which o important to the study of lar sentiments and emotions, ray of life. common attitudes, ; and disapnointments. jov jorrow, beliefs, customs and ners and scores of other as$\therefore$ or if anvthing worthwhile been done in this connection. ther scanty. Perhaps some nies Dublished in this country printed a selection of "do- baitis," something like quatrains but on different meters, without any attempt to interpret them. or maybe folktales like that of "Siah Moy and Jalali" have been published. Yet, much research is needed in this field due to its immense importance. In other words, folk speech should be collected and classified according to each area which has still preserved its characteristics. No doubt this will be a difficult task but it surely shall be rewarding, calling for relentless efforts on the part of those who deem serving this cause one of their national obligations. Folk speech represents human emotions par excellence. Man is always influenced and impressed by beauty or ugliness and other reflections in life. Once, he feels joy by seeing something splendid. Another time, he is grieved by something shocking. However, in both cases, he reflects his impressions or emotions in one way or the other. In order to convey his emotions to others, man has always been thinking to devise ways. Painting, sculpture, dancing, singing, music and literature (both prose and poetry) have been means or mediums of expression for such emotions since times immemorial.

By literature, we mean both re- 
corded and mrecorded letters or folk speech as the latter cannot be excluded despite the fact that in some conntries this type of literature has been recorded, in others, like Afghanistan, it has not. The opporturity had not arisen for this. As the recorded prose and poetry in Dari are considered a great document for knowing about the life of our past and present compatriots, in the same manner the folk speech is the most valuable means of probing into emotions and sentiments of those who inhabit the skirts of the mountains or live in valleys in various ways. In this type of literature, one can see vividly friendship and enmity, chivalry and cowardice, loyalty and betrayal. union and separation, hard work and idleness, haste and hesitation and such like reflected in constant confrontation. Hence, sustained studies are required so that the way may be opened for those who will, one cay, attempt to do research in this field.

The College of Letters and $\mathrm{Hu}$ manities. Kabal University, has always encouraged such studies. especially on the part of its instructors so that on the one hand nough light could be shed upon various aspects of literature and valuable works be produced for students of this field, on the other. One of these, Abdul Qayeum Qawim has written a monograph for his academic promotion within one and a half years it includes Dobaitis, songs, Proverbs, and Folktales current in some parts of
Takhar. He has recorded this in the course of his travels andas a result of conversations some informed people whose fooperation he has acknowled fd with thanks. He surely is awre of the fact that his first attemp in this field may have some shytcomings and therefore he modstly hopes to be of a little servce to those interested in this typefof literature.

According to his monograph. folk speech is broadly clasjifted into two catagories, prose and poetry, each of which again falis into lyric, social or religious subclasses. The ingredients of rolk speech are described here according to the Dari alphabetical order and interpreted or explained as deemed necessary.

\section{DOBAITS}

Dobaitis are called variously in various places. For instance, in Panjsher, they are referred to as "Sang Gardi". in some parts of Takhar like Chahab, as "Falak" and in other parts of the couniry as "Charbaitis".

Since dobaitis mostly do not have any known authors, they should belong to the folks. Following are some from Takhar with interpretations thereof :

"Let me make friends with this weaving girl,

"And become crimson silk in her loom.

"Her brass shuttle eravels between her two thumbs.

"Let me lie like bolts of cloth beside her." 
This shows that a boy has falin in love with a girl whose fainily continues the weaving tradition as evident from the words used in the dobaiti. It implies that he had the chance to sit beside ner. The fact that the word shuttle is used in a way to indicate the continuation of a movement makes it clear that he enjoys her favours, continuously.

"I am terribly bored with these tree leaves,

"And in this mountainous habitat.

"I have resolved to leave this place.

"Yet, I have fallen in love with one of the natives."

The adjective "bored" in Dari means "deltang" which is a com. bination of "del", meaning "heart" and "tang", meaning "depressed" and often the heart is likened to leaves as it is popularly said "My heart shakes like the tree leaves."

"Your dress looks like a flower with two tones.

"Your slanted eye-brow resembles the arch of a native violin.

"I have been hearing that you are going to have another love.

"Your new lover is a lazy oid dog."

As is generally the case, girls do not have much choice in selecting their husband due to the prevalent arranged marriages. The dobaiti shows that the girl has been chbsen another man for her future husband by her father. However. the man who loves her blames it all on her, though unjustifiably.

"Oh my love, you have made four home up yonder.

"And adorned yourself like a pigeon.

"I would like to become a hawk and catch you from the brink of the precipice.

"And catch you so gently that none of your feathers may fall" The above dobait is a splendid example of natural but also gentle feelings of a lover toward beloved

"I wish I had not noticed this darned house,

"So that through seeing, I could not be tormented.

"What a night! They are we-

"Tears suddenly fall on my theeks as if blood flowing from my liver,."

This dobaiti is indicative of separation and jealousy, obviously a scourge suffered by all who are passionately in love.

"What o night! They are wedmy sweetheart.

"And are separating us.

"A light is burning in the room upstairs.

"Those witches are talking her into it."

Since most of the marriages in the villages are still arranged. old women, often close relatives such as aunts try to convince young $\mathrm{si}$ rls to change their minds about their loves and marry someone else, preferably with lots of land or riches.

"I left home and said oh Cod!

"I left behind my sweetheart for ever.

"Friends and brothers. remember me.

"I embarked on a journey without the hope of returning." disenchantment or disillusioumen: Such journeys are the result of 


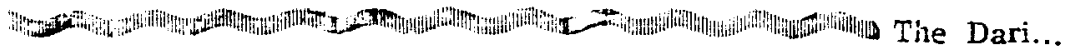

especially in love and often nothing can bring the man back to his home or native village.

"Oh, love, don't be: afraid of bickering.

"Sit under the shade of flower and don't worry about thorn.

"Eventually, lovers go to the gallows.

"Walk like a man and don't be scared.

Love before wed-lock, especially making love, unleashes the fury of both families but more so of the girl's. If they catch the two in the act, the lovers could be fired upon. So there was need for caution on the part of the man.

"I have got a flower in my collar.

"Wherever I may go, your love is with me.

"Wherever I go, I come across ruaning water,

"That is the result of my falling tears."

Weeping for the sake of love makes girls adorable and is not shameful for men. On the contra$\mathrm{ry}$, it bears evidence to their suff. ering and devotion which rules out rest or patience. ing.

"I wish I know about your com-

"I could plant roses and jasruins, along the road. After planting the roses and jasmin.

"I would rub the dust under your feet on my eye-lids."

The last line, very often quoted, reflects the highest degree of devotion and dedication in love amsng the common people.
"Oh sweetheart, it is difficult to reach you.

"And it is more difficult to hear a nice word from you.

"It is easy for me to fall in love with you,

"But one may die and you may still stay quiet."

Girls of a few words often prove trying, especially for lovers who are thirsty ta hear a nice word $\mathrm{fr}$ om them. But they still bear this for the sake of love.

"The cloud ses from the shore of the Khorasan river.

"And pearls fall off the lips of the yout.

"Oh blast the roosters crowing early at dawn.

"Making the lovers leave their sweetheart grudgingly."

White teath are often likened $t_{0}$, pearls. In the above case, it is meant that when a young boy and girl start talking, it looks as if pearis are falling down.

Since most of the common people did not possess watches and many of them still don't. the. only way in which they told the time was to listen to the roosters. told the time was to listen to the

"Nobody succeeds in climbing the Taluqan Pass.

"The earth is not satisfied with mankind buried in it.

"I wanted to approach the one who predetermines death,

"And tell him death is inevitable, but let the young grow old."

To simple people walking barefeet, the Taluqan Pass looked as insurmountable as death itself. But the universal craving that the young should not die a premature 
death has been amply expressed.

"Up above is the God and down below my beloved.

"I have to regret for my wounded broken heart.

"I did not consent to be away from my sweetheart.

I have to bow to God's will being done."

Belief in fate or predetermina. tion has been strong throughout the country, and more so among the common people who express these utterances. This provides them with a kind of solace.

"Oh boy, why did you put on that turban?

"I have fallen in love with you but you don't care.

"I swear to God I am in love with you.

"Why do you put on that turban of cowardice?"

Turban among Afgan symbolizes manhood and courage. And cowardice is something abhorred by women everywhere. If a girl tells a boy she is in love with him, he often reciprocates the feeling. If she comes to his parent's house to stay there, he has got to marry her.

"Oh faithless one. come and be faitful to me.

"If I abandon you, you may : $u$. rse me.

"If I abandon you out of faithlessness,

"Take up your sword and chop off my head."

To an Afghan woman, lack of faith or faithlessness or infidelity looks like a serious offence and punishable by death, if she has the power and the authority.

"The stars began to shine and I was awake.
"I was lying behind the broken fence.

"The darned rooster started to crow, announcing the dawn.

"I was still awaiting my sweeth. eart."

This time. the girl may have stood the boy up, probably because one of her parents or a big brother or sister was awake too and she couldn't make it.

"Oh, I adore that archway.

"And when I hear your voire, I suddenly stop.

"I hear your voice from far and near.

"This freshes me up like a flower bud."

Hearing the voice of one's swe etheart is a source of joy everywhere. but in countries where men and women can not mingle il. freely as they desire, it is a real pleasure.

"We four brothers were all alone.

"And came from the Upper Qa. ratagin.

"Tell my mother not to mourn our death.

"We were destined to be drowned in water."

This may have been uttered by one of the four brothers who pro bably did not know how to swim and out of desperation they hac taken a plunge into a rive to esca pe some imminent danger.

"Don't sprinkle the salt on a fr esh wound.

"And when you kill me. don fill the town with its news.

"After killing me, shroud m with your own hands.

"Don't let the strangers bur 
my body."

This shows the height of devotion a lover can nourish for his beloved. A real devotion indeed. And he forewarns her not to allow the folks to gossip about their relationship so that her reputation may not be spoiled and thus ruin her future.

\section{SONGS OF TAKHAR}

One of the famous songs of this province in northern Afghanistan is known as "Alghana Jan" which is sung to a dance similar to the attan", the well-known Pashtun folk dance. Younger boys and girls sing this while making a circle, hand in hand, whirling around. Following are the lyrics:

"Alghana Jan Alghana, sitting under the mulbery tree.

"Don't lean on the red chest. It mas break.

"I wove these locks and I wove those locks.

"And I shoved them all behind myself.

"Our Mir" -Chieftain- swore again, divorcing his wife.

"Abdullah Jan on the pass with his spotty horse.

"A javelin has pierced through his liver. Kokhor in grief.

"Hey, hey, the poplar leaves.

"The girls are sitting in a row, eating pomegrenates:

"Whose locks are these? Osay's.

"Our Mir set out towards Qalminzar.

"Qalminzar is covered with tulips, red like calf's blood.

"Oh you little one coming behind me,

"Where is he taking us to?

"Your lucky star is shining. They are preparing your wedding dais.

"The hubble-bubble water has made your hair long and jet black.

"And your face is full like a round bread. Your husband is Mirza Malek.

"Alghana jan Alghana, sitting under the mulbery tree.

"And all the girls are singing."

The names mentioned in this song apparently denote local heroes who were killed in a battle but did not have someane to mourn their death. The Mir or Chieftan swears that should he not avenge this, he would divorce his wife. But it is not known from song whether he was capable of doing so and thus his wife was lucky keeping her husband. Of course Alghana with the long locks was the widow of one of the slain heroes. "Osay" sounds like "Os Khan", a character from the legend of "Gor Oghli" whose fifty odd versions were sung in winter nights in northern provinces. This may be soon forgotten in the wake of radio changing forms of entertainment, unless recorded.

Following are shorter songs sung either solo or in unison.

Hey, hey hey

"Hey, hey. Under the "Khanaqa" mulbery tree.

"Khanaqa went to the bazaar, crying.

"The younger daughter in law kneaded the dough. eaded the dough .

"My father went to fetch burning wood.

"His sickle and rope are missing." 
"His sickle and rope are in our orchard.

"Our pomegrenates are like red apples."

The new gnest

"The water is coming from above. lau.

"And I smell the smell of pi-

"Sweep the room because.

"A new guest is coming." My Dearest

"My dearest, let us go to Kabul, "To watch the flowers there.

"I wish to become a love in your parlour,

"And open your locked collar.

"Further, I wish to become dust,

"And lay on the rows of your eye-lashes."

Girl Friend

"My girl friend, my girl friend.

"Let us go under the "dolana" tree.

"And ring our bangles thare.

"In such hard times, we must appreciate each other,

"And sing friendly songs together."

The Velvet Dress

"The entrance to her abode is swept,

"Sprinkled with almond blossoms.

"A velvet dress is worn,

"By my lovely sweetheart."

The Nomadic Girl

"My daughter is sitting on top of a hill,

"Milking a white sheep.

"She is making "qoroot" -dried lumps of yoghurt.
"And is wearing a cheet shawl " PROVERBS FROM TAKHAR

One cannot hide the sun with two fingers.

Don't try those who have already failed you.

Fish in troubled waters.

Attractive container makes you drink water.

When there is water, you can take ablution.

When you are drowned, no matter how deep the water is.

Your own relatives may join forces with the enemy.

Don't ask a new rich for credit, if you do, don't spend the money.

Oh man, the memory of good deeds or bad ones linger on.

Threaten him with death, he may aquiesce to fever.

Oppression reduces one to $\mathrm{mi}$ sery.

Tell me your companions and I tell you who you are.

An imbalanced load does not reach its destination.

I don't complain about the food but I do about my position.

Tell your friend the truth and brag with your enemies.

You have to struggle as long as you live.

The man bitten by snake mas die when opium (medicine) is brough from Iraq.

You can settle every score in the outset.

A melon turns yellow, seeing the other. 
They are not allowing ine to enter the village, put my horse in the chieftan's stable.

The snake hates the mint and it grows in front of its hole.

A man bitten by snakes dreads the long rope.

The brook is larger than the orchard.

Watch your possessions and don't blame anyone for theft.

What is evident, there is no need for telling.

The calf is unruly because it is encouraged.

Don't rap my door with one ha- nd or I will rap yours with two.

You cannot hold two water-melons with one hand.

Wherever the road is rough the lame man is to suffer.

One cannot become an iron-smith by blackening one's nos?.

He can not hit the donkey, so he hits its saddle.

The butcher sells his meat and the orphan wastes his tims.

Put your fractured skull inside your cap and your broken arm inside your sleeve.

The smaller loaves turn red sooner. 


\section{By N. Sahraii \\ The story of a greedy merchant}

May be it was, may be it was not, there was a merchant. He had seven sons but no dacghter. The merchant was so gredy and miser that he wouldn't spare even a coin to help the poor. He loved his money more than every thing else.

In front of the merchant's palace a poor kuchi had erected his camp. He used to take milk and yogurt and cheese to the merchant's home to sell at very low prices. One day an old woman with very rugged clothes entered to the palace. The merchant's sons and servants thoughit that she was a begger. So they wanted to turn her off the home. But the old woman started 0 run and reached to the merchant's wife.

She took an apple out of her bag and gave it to the merchant's wife and said, "Eat this apple and you will bear a pretty daughter." The merchant's wife was very pleased at this. She took the apple and ate it enthusiostcally with the hope of bearing a daughter. At this moinent the merchan's sons had arrived in the room. The old woman left the house and said good-bye adding that she was the angel of marriages and she had tied the bond of the new girl to the name of that kuchi's son who lived in front of their bouse on the other side of the street She then rushed out of the house. The merchant's wife and sons ran after her but all in vain because she ran too fast. They begged her not to do this but she soun disappeared.

At this moment the merchant came in and asked his wife what 
they were so anxious about? He felt very bitter and sad when he learnt about this. The merchant knew that the kuchi had a sir month old son. First he thought of obliging the kuchi to move to an other city by giving him some mones, but suddeniy changed his mind and thought, "If he is alive his danger will always be, even if he lived in amofher city." He knew that the kuchi was very poor and miserable So he conceived an other idea. He went to the kachi and said. "O good man. I like your son so much that I camnot enjoy life without him. If you let me keep him and grow bim up for you in my own house, In give you as much money as you wish. More over I'll return him to you when he is grown up".

The kuchi thought of all the difficulties of life he we suffering, moving always from one place to another with his few animals. And he thonght that his son can grow nicely and comfortably in a rich man's bouse. The ignorant kuchi accepted the proposal and gave his infant to the merchant and himself left for an. other city with some cash he had obtained from the rich men.

The merchant handed the infant over to his servant and urged him to kill the baby and bring his blood to him in a small bottle. The servant took the child out to a desert. But his tender heart felt sympathy for the innocent child, so instead of killing him he beheaded a pigeon and bottled its blood for the cruel merchant. The infant was slowly left in the desert alone in the mercy of no body bnt God.
Rariy in the morning the wandering kuchi was crossing the desert with all his camels, cows and donkeys when suddenly he saw a nice baby in the middle of the desert. He picked him up joyfully only to find that he was his own son. He thanked Gcd and went to another city to begin with a new trade. The child grew up strong and handsome. He heiped his father in his trade until they became rich and built a house of their own.

Leave this here now and hear about the merchant whose wife had delivered a beautiful daughter who grew up at the same time and became a most beautiful maiden. One day the merchant left his house for another town for trading and came to the city where the kuchi, now a merchant, lived. The merchant stayed the night in the knchi's house and saw a strong, handsome young man there, who spreaded the table cloth and brought food for him. The young son of the kuchi appealed too much to the merchant who asked the kuchi. "Is this young man your son?" The old kuchi told the whole story to him. The merchant knew that he was the same boy whom he had neglected in the desert. He was much worried to think that if this boy married his daughter he would at the same time get part of his wealth inherited to his daughter. The greedy merchant who loved his money conceived the idea to elininate the young man by any possible means. He cleverly asked the kuchi to let his son take an important message from him to his family. For this task he of- 
fered a good amount of money which was accepted by the kuch:. The merchant wrote a letter to his elders son asking him to kill the bearer of the Jetter as soon as he could.

The young man left the house to take the merchant's message. He crossed the vast desert with all its difficulties and pains and, to cut short the storey, be reached to the city. He went to the merchant's house, knocked at the door. At this moment all the merchant's sons were out.

And his daughter who was young and attractive by now, opened the door for him. In the very first gaze she fell in love with the man, not with one but with a hundred hearts. When she asked him what he wanted, her voice was shaking. The young kuchi too fell in love with her. He gave her the letter asking her to hand it over to her brother.

He himself relaxed under the shadow of a tree in front of the house. Thinking deeply about the young man the merchant's daughter thought, "Let me read the letter to see what is written in it". When she read it she was highly surprised and immediately thought to do some thing about it. What she did? She tore down ihe letter, and wrote an other one mentioning that she should be given to the bearer as his wife immediately". She also wrote that a big marriage party should be arranged to feed the hindu and the Moslems accordingly. At the bottom of the letter she signed her father's name.

At night when her brothers ca- me home and read the Jelter, thinking that it was really their father's writing, they brought the kuchi in, welcomed him with honours. They soon chanyed his clothes to new ones and married them the following day.

When a few months passed, the merchant returned to his house thinking of marrying his daughter with his nephew who was also a merchant. This man had earlier asked her hand in marriage but the girl was not the least consented with it, because, in the first place he was a rather old man and secondly he was very stingy and loved his money more than anything else. Moreover he was always grim and looked glnomy and unhappy. When he entered the house he saw the iruchi relaxing on the cushen with his daughter pouring tea for lim. He was highly enraged when he first saw the scene but when his sons told him that they married his danghter with the kuchi according to his recommendation letter he understood the whole situation but tried to keen his temper and congratulated them. Of course he tried to appear as happy as possible with artificial laughs.

When he went to bed at night he thought and thought worrying about the hundreds of thousads of Rupees that his son in law might get when he was dead. In this worry he didn't sleep the whole night until he plann. ed an other plot to get rid of the boy. He told his daughter that he had invited some guests forthe next night so he would like his daughtr to tell her hus- 
sauband to order some oiled and sweetened loafs of bread to the baker because if he left the job. for his servants the baker wouldn't prepare it as good. The merchant himself goes to the baker and offers him a lot of money and tells him. "Early in the morning a man comes to order some oiled bread. you simply push him into the oven and shut its top". In the morning the merchant's daughter did not wake up her husband and prefered to leave the job for the servants. Suddeniy the young man wakes up and remembers that he was asked to go to the baker. But his wife does not allow him and tells him that the servants will do it for him.

Now the merchant himself got up early in the morning, put his pustin on his shoulder and went to the public bath. When returning from the bath he thought of going to the bak- ery to ask about his son_in-law. He went. straight to the baker's shop and asked."Have you bak. ed the bread which ...."He had hardly started $h$ is words when the baker, thinking that he was the sender of the merchant, pushed him hard down to the oven and put the slab on it.

His sons waited and waited but the merchant didn't return at all. After searching for a couple of days they gave up and thought that he might have died.

The merchant's sons were rather lazy and unable to perform the works left for them by their greedy father. Seeing that the kuchi boy was a worthy and. hard working person they handed over to him all their business and he then possessed all the property and the wealth of the merchant.

God accepted his wishes, may $\mathrm{He}$ also accept ours. 


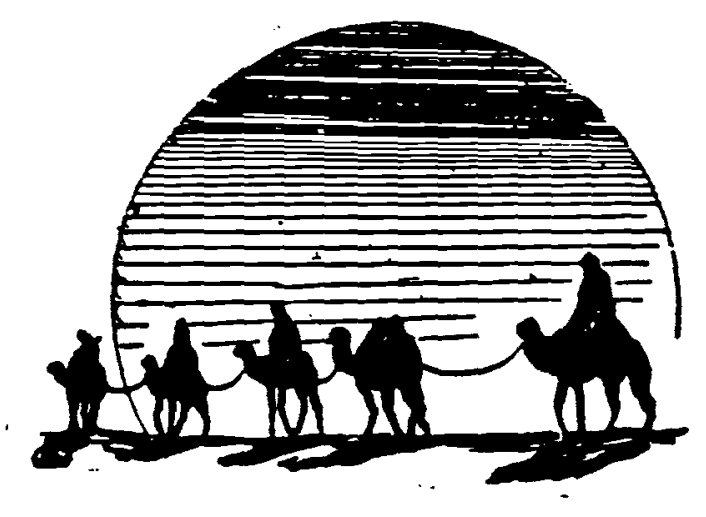


Folklore bi-monthly

Volume II. No. V. February -March 1975

Editor: Nessar Ahmad Behin

EDITORIAL BOARD:

S.N. Kulali, chairman

Nurullah Sahraii.

M. H. Nazihi.

Reshad Wasa

Assistant editor: Zohra Chopan

Photographer: M. Mashim Abbasi

Address: Ministry of Information and Culture, Kabul, Afghanistan. Tel: 26653

Editor,s 20451-3-Ext. 48
Annual Subscription :

Kabul :Afs. 70

Provirces: Afs. 80.

Abroad: $\$ 6$.

One Issue: Afs. 15.

Folklore Department, Bank Account:6001.

Subscriptions may be paidcash in Editor's Office.

Covernment Printing House. 


\section{Folktales of Parwan}



Some fifteen to thirty kilometers to the south of Bagram there was a Monastery called Rahula. According to the narrations 
it was built by a Minister of an ancient ruler of Bagram. The Monastery was later named after him as Rahula .

They say that a bright light shone from the top of jts dome on religious days and festivities, and a fragarant liquid leeked out of the cracks of the stones with a musical murmur in the silence of the night.

They say that aíter finishing this monasetry, Rainuia dreamed of a man one night who came to him to say that This very magnificent monastery that he had bult, lacked a memoreal gift The man suggested, "Since the king and the people are coming tomorrow to attend the inaugural ceremonies, entreat the ruler to offer to the monastery something before its inauguration".

On the following day when the ruler appeared before the public, the minister, Rahula, stepped forward, put his hands on his chest in the manner of respect and said, "We entreat your Majesty that the first offer to this worship place should be made by your hand." His entreaty was accepted.

Rahula was standing at the doorway. When the public were flooding in and rushing towards him, he saw a man amongst the crowd, carrying a box in his hand.
The minister called upon him from a distant,

"What kind of offer is yours?"

"It is a souvenir from Euddha," said the man.

The minister said," It you want your souvenir to be safe, give it to me".

The ouner of the souvenir said, "All righ, sce it but give it back to me, because, before I leave it with you I want to show it to the ruler."

Fearing that lest the rular realize the importance of this gift and turn his own fromise down, Rahula did not return the box to its owner and went to his own monastery, the Saatgarama. He climbed up to the cupola. In response to his prayer the dome's stones cracked open and the minister went into the gap thus formed to hide his valuable gift in it. Before he could get out of the gap the cacrked walls closed again and Rahula was caught inside.

When the ruler learnt about Rahula's intention, ordered his men to search for him but when they reached near the monastery it was too late and no trace of Rahula could be seen. That is why still a dense liquid like a black oil pours out of the cracks of the monastery's walls. 


\section{(2) The Story of the Watern dragon Naga and its fight with Kanishka}

About 10 kilometres to the north west of Bagram on the top of Salung Mountain, flows a great river in which Naga, the River. Dragon lived in anciant times. He ruled in that river and most of the natural powers and elements such as the winds, the rain, the snow and ice were in his power and under his anthority. At that time a great scholar named Erhat was living in the vicinity of Bagram. This learned man was on top of the list of all his contemporary men of knowledge. It was for the sake of his wisdom and knowledge that the water dragon. respected him and always sent him gifts and presents. At lunch time, close to the middle of the day the learned man with the help of his spiritual powers would sit on a mat which took off from the ground to take him to Naga's palace at the bank of the river in Salang. He consumed his lunch there.

One of his pupils got curious about where his master was going for lunch every day. He always asked himself, "Where he might be going?"

Finally curiousity made him decide one day to hang himself secretly at the corner of the mat in order to discover the. secret. Conceived with this idea. one day he hid some where near the mat and at the moment of its take off he caught hold of the mat and was flown up to the air. They instantly. reached to the bank of Salang river.

When receiving his patron, $\mathrm{Na}$ ga also noticed his pupil and invited him -as well for lunch. But the dishes brought for them were different. The food brough for the learned saint was a gorgeous heavenly meal while the one brought for his pupil was an ordinary earthly food. When the learned man finished his. lunch, he thanked Naga and asked his pupil to wash the dish in the manner he used to do at home. The pupil noticed the difference between the two meals when he saw the remains of his master's food. He was enraged and while influenced by his emotions and anger he prayed for the destruction of Naga and for himself to take Naga's place. Hardly a moment had passed when Naga felt a head-ache.

The learned savant after his thanks and prayers for the meal realised that he had done wrong by asking his pupil to wash his dish. Naga too regretted for having served two different kinds of meal. But the pupil returned to the monastery with a wounded heart and a desturbed mind: So he pray- 
ed and read religions prayers so much that all the world came under his inflnence. On that same night he died and his soul was transferred to a water dragon. While twisting in rage he dived into the river, killed the old Naga and he himself took his place with all his powers and authorities. He then intended to revnge his master. There fore he summoned all the snakes and let loose all typhoons, winds and rain. They all became active so strongly that the trees were uprooted, dust and fog filled the air of the Kushani city glooming the Monasteries of Bagram.

The great Kanishka was very surprised to see the sudden $\mathrm{ch}$ ange of weather and asked the great learned man of the capital to find the reason. The learned scholar who knew the whole story, told the king exactly what had happened. To commemorate and to console Naga, Kanishka decided to build a great monastery, one humdred feet high at the foot of the snow covered mountain. Therefore all the masons and labourers, architects and civil engineers went to the site to build the monastery.

Naga's successor was enraged again when he learnt about the decision of kanishka. $\mathrm{He}$ sent orders to the wind and rain to block the way to their construction work and prevent the plan to be implemented. When Kanishka insisted on his orders to be performed, the water dragon was further enraged. He doubled his destructive powers and the most severe snow and rain began to fall. Persistently, the workers built but the natural forces destroyed what ever was built. Six times the monastery was completed and six times it was ruined.

As a most powerful ruler, kanishka was ashamed of his failure and was enraged at the same time. So he ordered his men to fin the river with stones and earth so that it should never flow again. $\mathrm{He}$ also ordered to destroy $\mathrm{Na}$ ga's castle. With this aim he and his army came from Bagram toward the snow covered mountain. Naga was affraid when he saw the tremendous army. So he converted himself to an old Brahman and appeared on Kanishka's way, bowed respectfully and said, " $O$ ' great kanishka, Due to your personal abilities and statesmanship, you have become a powerful ruler. I am sure you don't have any hope that has not been fulfelled. I don't really understand why you take all this trouble to come out against the water dragon, Naga? Nagas or water snakes and dragons are very bad creatures. More over Naga has a great power; all the natural elements are under his influence. He rides on the cloud, gives orders to the wind to swirl and swish about in the blue sky and above the snow-capped mountains; he flows great floods and 
power can ever resist him The refore, I wish you $O^{\prime}$ great ruler to renounce the idea of fighting against him. Because in case you defeat him you won't gain any fame but if you are defeated you will suffer the pain of defeat and shame".

When Kanishka showed reluctance in forwarding his army the water dragon returned to the riv$e r$, dived under the waves and hardly an hour had passed when the weather was changed. Big masses of dark clouds gloomed the air and not only Bagram but the whole area of Kapisa with its vast ring of mountains was lost in the dense clouds and fogs. The roars of the water dragon echoed like thunder in the air of Salang. Mountains and rocks were moved and dislocated. The wind uprooted the trees.

Kanishka's army began to read religious prayers. Kanishka himself prayed, "My prevoius good deeds made me the most powerful man in the world; and with this power I weakend the powe rs of terror and conquered the world. Now the water dragon wants to over come my power. Therefore I approach to good deeds again and I pray that these deeds help with me on this occasion."

At this moment flames of fire shot out of his shoulders and smokes ascended all around him. Seeing this the water dragon escaped with fear. The wind stopp- and the dark clouts were broken apart: Then Kanishka ordered that each person should throw a big stone in the river until it was entirely blocked. The water dragon again changed himself to an old Brahman and appeared in front of Kanishka," I am the water dragon," he admitted", I am ready now : to obey you I hope that you will forgive me for my past deeds. Since I know that you love all the creatures and beings and protect them, I am sure that you will also have mercy to this poor servant." He added; "If you kill me, be sure that we both have gone to the wrong way, you for killing me and I for having enraged feelings and as a result we both will have to suffer in our future lives after the resurrection."

Kanishka heard his apologies but emphasised that he will. not be pardoned if he disobeyed his orders again. The water dragon replied", Naga was transformed to a snake because of his cruel nature. In Case he intended to commit any incorrect acts in future you should prvent him before he starts his deeds". He suggested that Kanishka should fix a big bell in the site before he builds it. And he should send some one to the top of the mountain to look around. He should immediatly ring the bell when he notices any dark clouds. The ringing of the bell would remind the water dragon of the great- 
ness and the powers of Kanishka." And thus my gloomy thorghts would vamish", asserted the ald man.

Kanishka accepted his appea1s. And thus with the terrifying sound of the great bell which took the signal of Kanishka's might and grandeur to the remote parts of Kapisa, the monastery and its cupola were built.

\section{The Story Of Parwan And Marwan}

In ancient - times two rulers were governing in the northern and south eastern parts of today's Parwan Province, one of them around the area which fo rms today's Jabal Seraj, and the other in the area of Bagram. These rulers were very sincere friends and according to certain narrations they were brothers.

The elder brother was called Parwan while the second one was called Marwan. Their territories were nicely built cities and the people under their domination were happy and welloff. Throughout their territories there were lush green gardens and pleasant medows with foami$\mathrm{ng}$ and roaring rivers running along in different places. Pleasant water falls could be seen Every where.

Parwan and Marwan were both free from the harms of enemies because if one of them was threatened by any aggressor, the other brother would rush to help him. They both had very reliable armies ever ready to fight or to defend their country against the aggressor.

The country where Parwan was ruling was full of Picturesque sceneries, lush green trees, big orchards, beautiful valleys and snow-capped mountains. The rivers Shutul Nilab and Ghorband ran through it to add to its beauty. In one side of the territory the peaks of Asheqan and Shamiana stood high while on the other side the dominating Salang Mountain, covered with snow, and the Khawak pass were seen. The third side extended upto the prosperous valleys of Ghorband while on its fourth side the Shekari Pass was situated with many extensive vine yards in the south Apart from agriculture, its people were also skillful workers of contemporary arts and industries.

Similarly the territory a which Marwan was ruling was a very vast area with extensive cultivable lands. All sorts of grains and vegetables were sown in it. In one side of it streched Mount Pahlawan with Nilab river running infront of it. On the other side were the charming valleys of Senjid-darra, Istalif, Guldarra, and the vine yards of Qara-bagh and Kohda man with their attractive scenes. This country had many cities of 
various sizes, and many villages, large and small, where people were busy in agriculture and other industries with great enthusiasm.

Because of the deep sincerity towards each other, Parwan and Marwan not only rushed to help one an other on the occasions of wars and difficulties, but in the time of peace too they visited each other with big festivities and honours. The people of the two territories too had friendly relations and communication among themselves, Particularly in the exchange of trading materials and goods.

One night when a big feast was arranged in honour of Marwan, the elder brother asserted that in case one of us are suddenly attacked by an aggressor, what would be the easiest way for the other of us to be informed soon and to rush to help immediately. This assertion was very important and valuable. Because despite the delivery of messages by quick messengers riding very fast running horses it took a rather long time to inform the other.

After some discussions and exchange of views they decided to extend an iron chain from one capital to the other. So that when one of them vere under a surprise attack should inform the other side without waisting time by pulling the chain. This decision was implemented im. mediately and the iron Chain was extended to join one capjtat to the other. because of this closely linked relations and from the fear of their mlitary might no aggressor could dare to invade their territories.

One day Parwan wanted to test his orother's vigilance and readiness in time of danger. He wanted to see whether his brother's army could reach to the battle ground when the chain was pulled. Therefore, he ordered his men to pull the chain His order was acomplished and the chain was pulled several times.

On that side Marwap was enjoying himself in a drink party in his castle when the chain was pulled and interrupted his enjoyments. He ordered one of his officers to call the army and send it soon to the battle field. This officer and many others prepared the army and the war equipments and in a matter offew hours the ruler of Bagram with several thousand of infantry and cavalry soldiers, with all their arms and amunitions, rushed to the country of Parwan where they reached after about six hours. The advance group reaching the city were extremely amazed to find the city calm and quiet. Althought they informed the ruler of Bagram about the situation but never the less Marwan came to his brother's court. 
Marwan's army was settled some where while Marwan and several of his officers went to Parwan's palace. When Parwan learnt about his brother's coming, received him warmly. In response to the enquiries of Marwan about the situation, Parwan, being ashamed of what he had done, apologised and said that he only wanted to test the vigilance and speed of his brother.

Although Marwan did not say any thing, yet he was very annoyed and upset. With the huge army he had brought from Bagram he did not consider it right to stay any longer there, so he returned to his capital.

A few years had elapsed when the chain's clinging was hea rd again in Marwan's court. Marwan in the middle of enjoying a party thought that his brother was again examining his ability to help. Therfore he considered it a mere play and did not bother about it. Incidentally this time Parwan was really under the attack of an aggress. or. While fighting back bravely, parwan was expecting his brother to reach to his help. The battle last for several days but no help was sent from Bagram.

Although Parwan won the batthe after fighting bravely,yet he was much annoyed of his brother's neglegence. Finally they got angery with each other and decided to cut the link and that was the end of the iron chain.

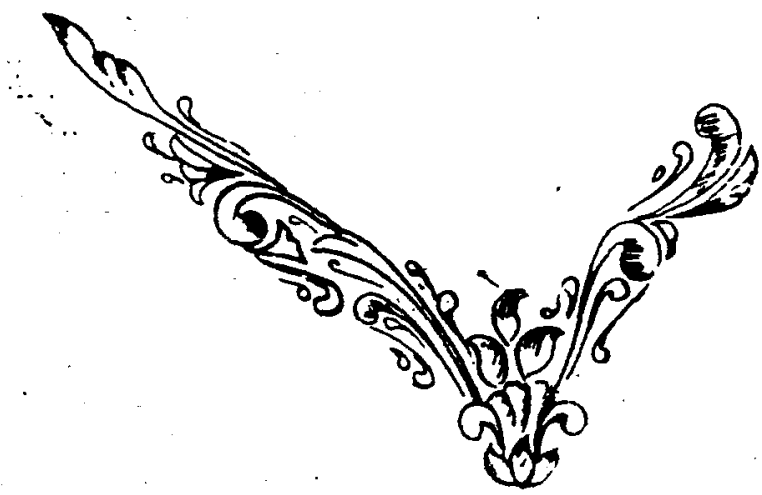




\section{THE DAUGHTER OF THE HEATH VENDOR}

By Siddiq Sultani

Translated in to English.

by Abdul Haq

Once upon a time, there was an old heath vendor. He had three daughters. One day, when he went to the moors to collect heath, he noticed heaps of it. He looked around but could not find any trace of another man. He shouldered his usual load and left for town to sell it. The next day, he went to the moor again and was amazed to see another heap of heath.

He carried his load to town and sold it. The third day when he was collecting the usual heath, he saw two loads lying there with a snake on them. He recoiled with terror, but the snake greeted him saying: "Don't be afraid, I won't hurt you. Only do what I tell you otherwise I will deavour you".

Trembling with fear, the old man asked the snake what was he supposed to do?

The snake answered that it was easy. He should give the snake the hand of his youngest daughter in marriage.

The old man answered, trembling, he would go home and tell his daughter about this proposal and should she consent he would not have any objection.

Elated, the sanke told him to go home and bring him the news.

The old man carried his load to town, depressed. After selling the heath, he bought a few loaves of bread and went home. When his daughter noticed her father's dejection, she asked him what was the matter. The old man said it was nothing. After she pressed him to tell the truth, he told her the whole story.

She said he did not have to grieve over this. $\mathrm{He}$ should tell the snake his daughter consented.

The next day, the old man went to the moor and was greeted by the snake. He returned the greeting and told him his daughter consented to the marriage. Dancing with joy the snake said the wedding will take place Thursday.

The old man said he would'nt say anything. Whatever the snake liked would be all right with him.

The snake gave him a few gold coins and told him to buy a few dresses for his daughter and spend the rest as he liked. The snake also asked the old man to bring his daughter near a particular river on Thursday where he would welcome her along with his friends. 
The old man went to the bazaar with his daughter, selling some gold coins to buy, his da ughter a few dresses and shoes. Then the two other daughters beautified the bride with much misgivings and took her near the river. They were weeping out of fear that the snake would devour their sister. However, the bride consoled them, saying "what will be, will be."

A few moments later, a crowned snake riding on the back of a python emerged from the water, followed by a multitude of smaller snakes. In a moment, the river bank was filled with all sorts of snakes. Then the python crawled toward the bride, asking her to ride on his back. The bride bravely mounted on his back and the python carried her swiftly to the river, followed by others.

After a few weeks, the old man's two daughters asked him to go and bring them the news of their younger sister. He said he did not know where to go but his daughters suggested there was no harm in trying, so they baked a few loaves of bread for the old man which he wound around his waist in a cloth.

He walked and walked till he fell exhausted. At this juncture, two mina birds were flying. When they noticed the old man, one of them told the other he could go to a cave nearby, remove the rock blocking the entrance, squeeze himself through the window to come into a garden where his daughter's house would be.

Startled by this tiding; the old man hastened toward the cave.
He did as he was told till he saw the building. He made for it and noticed his daughter coming toward him. The old man started weeping out of joy. She told him she was quite happy. Her husband was a handsome young man and life was quite pleasant. She was only bothered by being away from them all.

The old man was flabberghasted, saying her husband was a snake and not a human. She told him her husband was a snake prince. He told her not to tell anyone about his coming till he went back to give her sisters the good news. When his two danghters saw him coming back, they hastened to greet him with enxiety and expectation. When they noticed how happy he was, they started kissing him. They asked him if he had seen their sister and he said he had. He told them proudly that she was very happy. The two girls asked their father to take them to their younger sister. He told them to wait till he bought them some dresses. The old man took some more gold coins to the bazaar. After selling these, he asked his daughters to choose their dresses. Then they all left for the youngest girl's home-, accompanied by one of their cousins.

The moment they saw their youngest sister, the two girls and their cousim embraced her and started crying out of joy. The cousin got terribly envious and resolved to do something to ruin her life. So she asked her what. her husband did for living. She said he was the prince of snakes. The cousin protested. The girl replied he was a snake all right 
when in disguise, other-wise he was a normal human. The cousin asked what was his name. She said when she was brought there, they called her Mehre Negar and the groom Sabzina Khumar due to the colour of the latter's garb.

Then her cousin asked where he was now. And she said he had worn his skin and gone walking for an hour. Her cousin said to herself she was going to do something about him now. She suggested to Mehre Negar to burn his skin so that he could walk like humans. Mehre Negar said his skin could not be burnt ordinarily. Her cousin insisted on seeing the face of the prince despite her misgivings. At night, when Sabzina Khumar returned home, he asked his wife who were the visitors. She told him her two sisters and cousin were there. Sabzina Khumar told her to welcome them on his behalf.

Mehre Negar did what she was told. The inquisitive girls hastened toward Sabzina Khumar's room but they could not see him. They insisted on Mehre Negar to ask her husband what could burn his skin. Mehre Negar on going to the bedroom at sleeping time asked him this question. Infuriated, he slapped her on the face. But Mehre Negar cried so much that he took pity on her, telling her not to bother about what others said. He told her his skin could be burned with those of onions and garlics in an oven but she should not tell anybody about this, otherwise they would ruin them. She promised she would'nt.

The next day when Sabzina Khumar left home, Mehre Negar came to the visitors who were talking about the skin. They talked so much that Mehre Negar got impatient and told them the secret. Her cousin collected onion and garlic skins all the time they were staying there. Then she heated the oven real hot. At night, when Mehre Negar and Sabzina Khumar were asleep the cousin crept into their bed-roomand stole the skin which she put into the oven with the onion and garlic skins. At this moment, Sabzina Khumar slapped Mehire Negar in a rage, saying she would not be able to see him anymore. Upon this Sabzina Khumar changed into a dove and flew away.

Instantly, she found herself and her visitors in the wilderness. They were at a loss not knowing what to do. Mehre Negar pledged to find her husband at any cost. So they all came to town and went to an iron smith asking him to make her a pair of iron boots and an iron cane. He told her these would be ready after a week.

After Mehre Negar got the boots and cane, she took along a few loaves of bread and started her search. She walked and walked till her boots and cane were worn out. She sighed out of disappointment, saying " $\mathrm{Oh}$ Lord, I repent and I hope You will pardon me."

Exhausted, she sat under a tree and noticed a few labourers carrying jugs of water on their shoulders. One of them said his master was suffering from heat and no amount of water thrown on him could cool him off. Mehre Negar thought it must be her husband. 
She asked the labourer to give him a drink. The labourer told his master that there was a wayfarer asking for a drink of water. His master told him to serve her some and bring him the remainder. Maybe this would cure him. Mehre Negar after drinking the water slipped Sabzina Khumar's ring into the jug. When the labourer poured water on his master, his ring fell off his body $\mathrm{He}$ put the ring on his finger and said he was cured now.

Sabzina Khumar realized who had come there. He went near the tree to see Mehre Negar in rags, exhausted. When Mehre Negar saw her husband. she rose feebly greeting him. Sabzina Khumar returned the greeting, asking her why did she come. She apologised for what she had done, saying she was betrayed by her cousin. Her husband admonished her saying he had warned her not to say anything about his skin to aryone but she had not listened. He said he now pardoned her but there was a snag. He could not take her home as his mother being the daughter of a giant wouIf devour her. He said she was too furious about what Mehre Negar had done to her son to spare her.

Mehre Negar asked him what could she do then?

Sabzina Khumar answered he had an idea. He would change her into a needle and put her in his collar. She consented. Thereupon, Sabzina Khumar said a prayer and turned his wife into a needle. When he came home, his mother shouted that she smelled the smell of a human. He said there was no human but if he wanted to eat him she was welcome.

The next day, Sabzina Khumar changed Mehre Negar into broom and placed her in a corner of the living-room. His mother again said she smelled the smell of a human. Enraged, Sabzina Khumar told her what could she do if there was one. His mother shouled she would devour her, Her son replied in that case she would cause the death of her own son.

Then she asked her son to produce the human for her to see. He told her he would comply providing she pledged not to hurt her. Upon her pledge, he changed Mehre Negar back into a human.

She asked who this woman was. Her son told her she was a woman most helpful to him. He could not introduce Mehre Negar as his wife out of fear because she would instantly devour her to avenge the sufferings of her son.

When Sabzina Khumar went out, his mother asked Mehre $\mathrm{Ne}$ gar to fill the trough with her tears. Mehre Negar wept and wept but the trough was not haIf-filled. The sun was getting hot when Sabzina Khumar noticed his wife shedding tears. He ask. ed her what was the matter. She said she was asked to fill the trough with her tears. He laughed at her simple mind. asking her to bring some salt. When she brought the salt. he asked her to fill the trough with water and add the salt to it. Then he told her to take the trough to her mother-in-law. 
After Mehre Negar handed the old woman the trough, she roared in protest saying this was not her diong. Someone else must have given her the idea.

The next day, when Sabzina Khumar went out, the old woman gave her a black rug and a cake of soap to wash it at the brook so that it may be bleached white. She washed and washed till her husband noticed her labouring so hard early in the evening. After he was told what she was supposed to do, he was furjous and said a prayer upon which the black rug became white. When she showed the old woman the rug, she was enraged, saying this was again not her doing. One day, Sabzina Khumar's mother told her sister this was high time for her son to get married to her daughter. Her sister consented, saying the wedding would be arranged in a week. Since the old woman was still planning to get rid of Meher Negar, one day she told her to take a letter to her sister and bring a musical box. She came across Sabzina Khumar on her way. He asked her abuot her errand, read the letter in which his mother had asked her sister to devour the bearer so that not a single drop of her blood may be shed on the floor Sabzina khumar wrote a letter on his behalf asking her to treat the bearer well and send the musical box through her. He told her to be careful to open the closed door and close the open one put the bones before the dog and the hay before the cow. He aduised her when she came across the blood stream, she should shout "what honey!" and after she climbed the steps and reached the living room, she should salute his aunt.

She left her husband and did everything he told her. After she greeted the old woman, she heard her roar, "Had it not been for your greeting, would have devoured you" Mehre Negar handed her the letter which she kissed and rubbed on her eyelids. Then the old woman gave Mehre Negar the musical box and told her to take care not to knock it about otherwise its sound would fill the whole worId.

When Mehre Negar descended the steps, the old woman shouted "The blood stream catch her! "The stream refused, say ing she had called it" the blood stream" for years while this woman called it "honey". She hollered at the dog and then on the horse to catch her. The dog said she had been feeding her with hay and the horse with bones for years while this woman put this right.

As she had reached halfway, a corner of the musical box was knocked at a wall by mistake and the ensuing sound filled the air till Sabzina Khumar came to rescue her. He hushed the sound and accompanied his wife, carrying the box. When the old woman saw the box, she said it was again not her doing. Then she asked her to sweep the room. 
The old woman went to her sister's and told her it was the wedding time. Her sister said it would be arranged the same week. When it was wedding night, Sabzina Khumar asked Mehre Negar to saddle two horses but not tell anybody about this. He said they must escape at midnight.

Sabzina Khumar went to the bazaar and bought a pack of needles, a mirror, a few cakes of soap and combs. Then he put a bottle of water in his pocket. At night, the people at the wedding party applied henna to his and his cousin's hands and put them in a covered carriage Mehre Negar was ordered to fix 10 candles on her fingers and lead the carriage. This saddened Sabzina Khumar's heart. When the candles were burning out, Mehre Negar started singing "Oh Sabzina Khumar, my fingers are burning!" Sabzina Khumar responded from inside the carruage, "Oh Mehre Negar, my heart is burning! "They were repeating this till they had reached the groom's house. The bride and groom were accommodated in a separate room while the guests started playing music.

Meanwbile, Sabzina Khumar seized the opportunity and stabbed her cousin to death. Then he took Mehre Negar and rode away on the horses till next morning. When the two old women hes too. came to awaken the bride and groom, they saw the door was closed. They thought they had sleepless night and let them rest for a while.

After sometime, they knocked at the door but there was no answer. They hollered and still there was no reply. So they crashed the door and 10 . they saw the bride in a pool of blood. Both old women hastened to chase Sabzina Khumar. When they saw the two horses in a wilderness, they accelerated their pace. As they were getting near them, Sabzina Khumar threw the pack of needles which formed a mountain, bleeding the feet of the old women. After the two managed to climb this Sabzina Khumar threw the mirror which formed a slippery mountain. But the two women again manged to climb this. Now sabzina khumar threw the soap which formed another mountain but the two managed this too. Sabzina Khumar finally poured the water from the bottle which formed a wide river. When they attempted to cross this, they were drowned, sparing Sabzina Khumar and Mehre Negar.

They came back to their old place. Sabzina Khumar said a prayer upon which their home and garden reappeared and they lived there happily ever after. May God grant your wis(The End) 

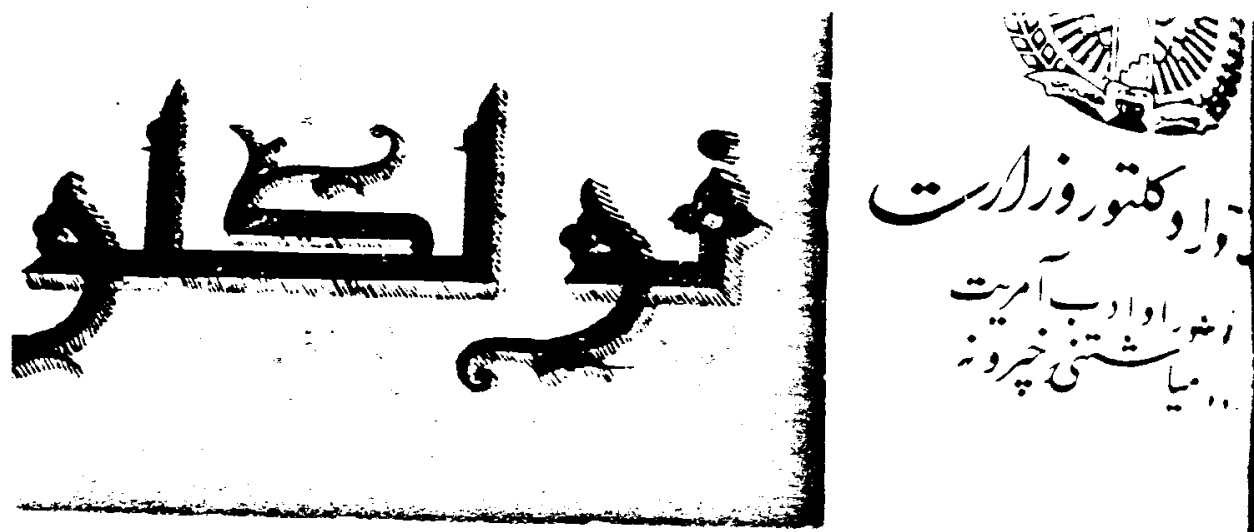

(p) كال بنحكه.

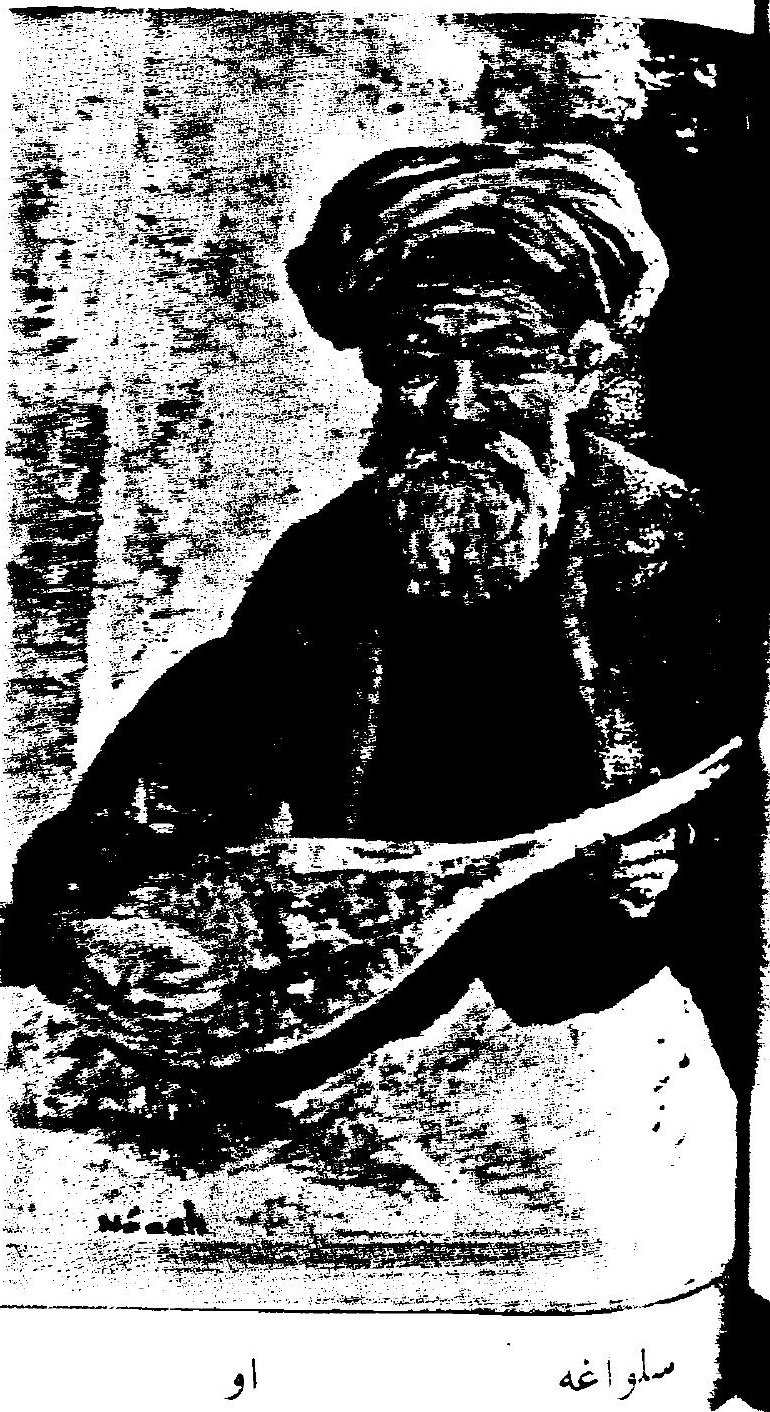






Information

and culture hly Magazine by the Afghan Department.

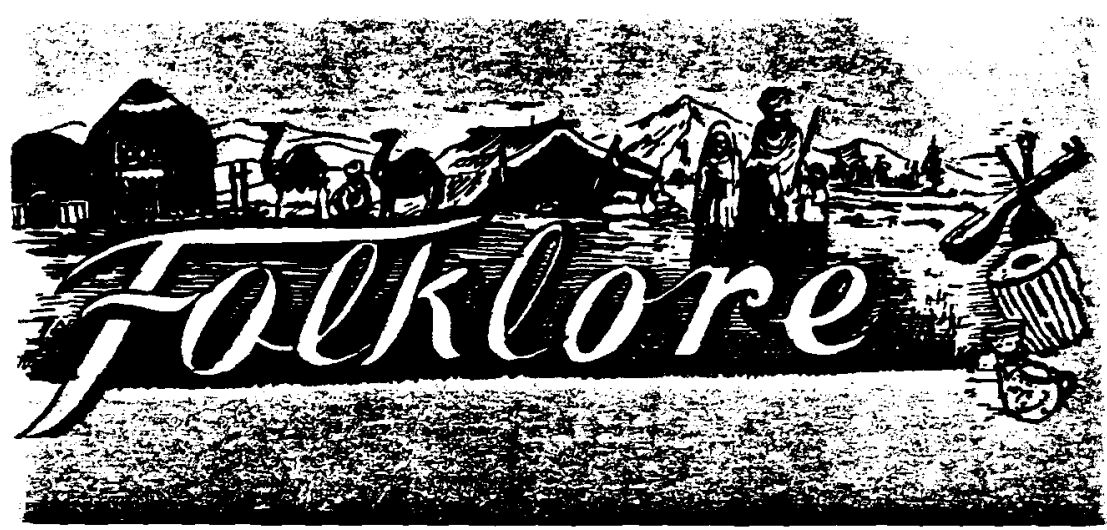

CONTENTS

Fine Arts in the Past

A Comparison of Folklore and letters

Oral Literature

PAGE

1 by Nessar Ahmad Behin

9 by Dr. Rawan Farhadi

16 Translated by Rahim Elham

The Effect of Folk Ideas

on Scientific Developments 19 by Hab.bullah Rafi

Anthropology and Folklore , 24 .Translated by N. Sahraii

Marriage Ceremonies and

Songs in Zadran

28" by Asadu'lzh Shohur

Parwan Flok Literature

34 by M. Hussein Yamin

The Eve of Barat

45 by M. Ayan

The Art of Gold Silver in

Afghanistan

50 by Reshad Wassa

Couplets From Teura

59 by A. Ghafour Hambaz

Stories and Riddles

63 by Ali Mohammad

The Fox

70 by Paeez Hanifi

Art of the Roof of World

74 by Enayatuilah

\section{ARTICLES IN ENGLISH}

A Comparison of Folklore and Letters

The Orphan

Birds Animals and Folk ideas

The Story of a Poor Prince by Dr. Rawan Farhadi

1 Translated by N. Sahraii

7 by R. Wassa

Translated by Abdul Hage

by Andishmand

11 Translated by Abdul Wadooc.

14 by Mehria Adell

Translated by Sabzikar

Front Cover: On a new camp side. A. Malik Rahmanis painting. 
Folklore bi_mon:hly

volume II. No. IV, December-January 1975

\section{Editor: Nessar Ahmad Behin}

EDITORIAL BOARD:

S.N. Kulali, chairman

Nuzullah Sahraii.

M. H. Nazihi.

Reshad Wasa

Assistant editor: Zohra Chopan

Photographer: .I. Hashim Abbasi

dress: Ministry of Information ad Culture, Kabul, Afghanistan. el: 26653

iditor,s 20451-3-Ext. 48
Ansual Subscription:

Kahul :Afs. 70

Previrices: Afs. 80.

Abrzad: $\$ 6$.

One Issue: Afs. 15 .

olklore Department, Bank A zccurt:6["].

ubscriptions may be paidcash in Editor $ミ$ Office.

Covernment Printing House. 
Written By Dr. Rawan Farhadi.

Translated into English by

Nurullah Saharii.

\section{A Comparison of Folklore and Letters}

A tale in the people's tongue, in Mowlana Balkhi's works in Ghazni and in the districts of Jami Herawi.

The task of comparing the valuable treasure of the country's literature and the people's proverbs and narratives leads us to considerable discoveries in the field of literary research. Exampla gracia, the presence of a tale in the language of the Afghanistan's people today as well as in the poetries of Mawlana Jalaluddin Balkhi and Nuruddin Abdur Rahman Jami Herawi is something very interesting and worthy of contemplation and meditation which forms the theme of this essay.

There is a proverb among our people. "man helam-O nahelad," which means I quit, but he doesn't quit. In the common language it is pronouced differentIv as. Ma Mehlum. Ou namehla. Here the use of the verb "Heshtan," to leave or to quit in the spoken language shows that the proverb belongs to the common language of the people in Ghor, Badghis and Ghurjestan, and that other Dari speaking peoples have learnt it later.
The implication of this proverb is such that some body approaches another person for want of something. but regrets it afterwards. But the other side insists upon him and rouldn't let him give up the entire idea. In such a case the fellow ivould say:

"Man Helam, O nahelad." Or. "Ma mehlum Ou namehla," which neans. "I give up but he doesn't." Similarly when a person has a claim on something, but wants to give it up. But the opposite side would not leave him. In such a case too, the first person says: Man helam, O nahelad, I give up but he does not. There are numerous cases in every day life similar to these two cases when a person would mention this proverb which is entirely based on a popular tale. One must know the tale itself in order to understand the real implication of the proverb.

Here a story is presented in the simple language of the common people: 


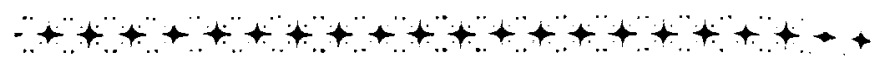

Flood was running down the mountain. Two persons standing near the water observed a black thing in it. One of the two said, "I think it is a skin full of ghee." The second fellow who knew how to swim, jumped into the water and swam to the skin full of ghee. He grasped the thing but soon found out that the black thing was nothing else but a black bear. The bear was struggling for his life and held him tightly. His friend, surprised by his companion's not returning to the bank, thought that the skin was too heavy for him to carry. Therefore he called at him: "You cannot carry it, so you better leave it alone." The swimmer called back, "I leave him but he does not leave me."

Dewan i Shams or Dewan i $\mathrm{K}^{\mathrm{a}-}$ hir, is not a mere collection of odes, sonnets, quatrains and other poems. All over this grand collection, the poems are conceived of valuable subjects on ethics, etiquetts and education. Regrettfully, no one has so far rendered any service to analyse the contents of this masterpiece of literature and thinking. In the Ode number 1288 of Dewan i Kabir (published with the auspices of Ferozanfer) the following verse, written seven centuries before us, appears on page 119 volume 3 .

Ba roz i sard yaki postin bood andar jo,

Ba Oor yuftam: dar jeh bejo, beroon arash,
Na poostin bood an, Khers busd andar jo,

Fetada bood o hamiburd $a$ : i jobarash,

Daramad ou ba tama,' ta ba fist i Khers rasid,

Ba dast i Khers bekard an ta= greftarash.

Eeguftamash ke reha kun $:: n$ poostin, baz aa!

Che door o der bemandi ba ran: , paikarash,

Beguft Ou ke mara poost: Chonan begrift,

Ke neist Omeid i rehaii :: chang i Jabbarash.

Hazar Ghutta mara medehad $b \equiv$ har sa'at,

Khalasi neist az an chang Aashe: afsharash,

Translation:

On a cold day. a skin was is the river,

I told a nude, Jump into th: water. take that out.

It wasn't a skin. but was a bear in the river,

Fallen in and carried down by water.

He went into the water witb greed untill he reached it,

The greed arrested him in the hands of the bear!

2 


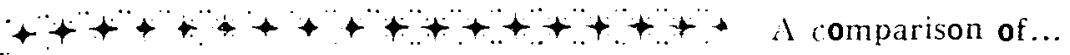

I told him, leave the skin and the bank of a stream, come back.

How far you have gone and how long, in its struggle?

Had approached to catch a fish, Suddenly a fish jumped on the surface of water,

He said that the skin had held him so tight,

That he had no hope of release from his cruel claws,

He streched his hand to catch it, His foot slipped and he fell in the water,

But he looked like an aired skin, The water was so swift and "A thousand time each hour he wide, that, droops me in,

No relief is possible from his nic, lover crushing claws.

Now we are going to open the "Selselat-uzzahah" of Mawlana Jami who has about fifty of his works recognized as having a high place. These works are collections of tales on ethics and education. The year of its first volume's compilation is $876 \mathrm{H}$. corresponding to 1472 A.D. ie exactly five centuries ago. Its title is,

"The story of a bear carried away by flood water:"

A man who saw a bear in the water thought that it was a skin blown with air. He went to get it, but he was caught by the skin. Another man from the shore shouted upon him, "Leave the skin and come out of the water. The man answered," I have left him, but he wouldn't leave me."

Now here is the story written in poetry:

He struggled a lot, but all in vain,

Finally he just yielded to the current,

Like a skin with its hair still unshaved,

full of things and luck,

It was floating on the water surface,

Going on with no hope of life or safety,

Two swimmers away at the bank, Were hurrying for some task.

Their eyes were suddenly caught by the river,

I And in wonder they looked upon that objects,

What could that be, alive or dead,?

May be a skin full of materials! "A bear with greed of a prey, on One of them stayed at the bank, 


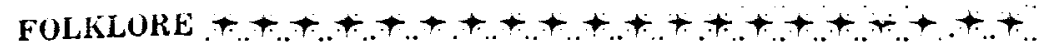

while,

The youngesters saw its back

The other one dived into the wa- and suggested, "Professor, there ter,

He swam untille he reached it, The bear himself was seeking a partner,

With both hands he struck the swimmer,

The swimmer couldn't swim any more,

With all the surrounding waves, fed up with life,

He ever and anon going up and down,

Seing his condition, his friend from the bank,

Called up on him, "O my dear friend,"

Leave the skin if it is too heavy, And let it go with the waves and tides,

He answered, "I have left the skin,

I have already renounced it,

But the skin wouldn't leave me, and

With fingers' pressure is breaking my back."

In the book "Feyh-ma-Feyh," written by Mawlana's associates the story is quoted from him in the following manner (page 115, published under the auspices of Ferozanfer, in 1348):

They say that a poor teacher had put on a single cotton shirt in a cold winter. A bear was being carried down the stream by flood from the mountain gorges. Its head was hidden in the water.

is a fur coat in the stream; you are feeling cold, go and get it." The teacher, severely suffered from the cold weather jumped in to get the coat. The bear caught hold of him. The Professor was grabbed by the bear. The youngesters . shouted, "Proffessor, either get that poostin, or else just leave it if you cannot carry it." The teacher replies, "I am leaving the coat, but the coat wouldn't leave me. What can I do?"

Then Mawlana explains the story:

"The interest of right will not leave you. Thank God that here we are not on our own, we are in the hand of the right. Here too we find that the story in "Feyh-ma-Feyh," like the one on Dewan-i Kabir gives a good meaning to the grabbing of the bear.

From this comparison it is concluded that Jami had not read a copy of the book "Feyh-maFeyb" containing this story. Otherwise he would have interpreted the story in a different way.

The significance of the Dewani Kabir's text is that it is the exact words of Mawlana Jalaluddin Balkhi while the text of "Feyhma-Feyh" is written by his associates and pupils. It is not for sure whether they had written it in "Majlesi Tazkir wa Irshad" or after that meeting or some other time after the death of Mawlana.

A careful study of both the poems, i.e., the work of Mawlanai Balkhi and Jami Herawi explains 


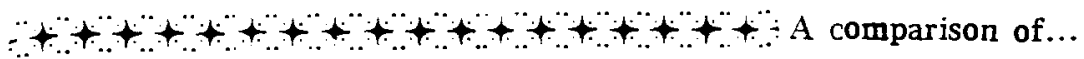
the fact that this section of De- Balkhi gives another meaning to wani Kabir had not been at the the story. He does not consider disposal of Mawlana Jami. This the bear a cause of hateful fact could be observed not only tricks and plots. Mawlana of in the statement of the story but Balkh, on the contrary, defines also in the explanation of ethical the grabbing of the bear as someand educational objectives.

In the text of Selselat-uzzahab, in the context of a few verses carrying the story, and as we are quoting it here under, the greed is presented by the bear who was catching fish, and the renouncement of the tricks which won't lead to any suitable place is mentioned for the purpose of impressing the reader not to misunderstand a bear or a boar with a spoil. Before dealing with the story of the bear, Jami gives you advice on the plots of tricky, illwishers :

They create hundreds of plots every where,

In order to mix with you again,

You may give up those malices, but,

Surprisingly they wouldn't give you up.

You can never free yourself from them,

Like the swimmer you may be trapped with the bear.

He then presents the story of the bear considering it a source of lessons, so that man should avoid ill-wishers and plotters, and should not mistake them for wellwishers. But Mawlana Jalaluddin to the attraction of love and its appeal to the heart and soul of man. A lover, like that swimmer, is suddenly caught hard in the grips of love to the extent that despite the counsel of wisdom, the strong grips of affection would not give him an opportunity, and despite his decision to leave it; love will not leave him.

Here under two more couplets, of the same ode, from Dewani Kabir, are quoted which relate to the story of "The skin and the Swimmer."

Although he is in possession of wisdom, and very learned,

His garment and turban is in debt of love,

So many hearts that were upset by love, which,

Dragged them, without giving them relief.

This difference in the interpretation of the story supports the thought that Jami had not been aware of the ode and the story written by Mawlana Jalaluddin of Balkh.

What is interesting for us today is the presence of exactly the 


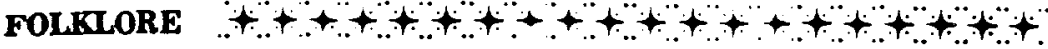

same story with two different nar- ple, than that of Mawlana of ratives in the poetical works of Balkh, as Jami himself is closer two great men of Islamic teach- to our time than Mawlana.

ings. The very same story exists among the common folk, on the basis of which a common proverb has gained wide usage among the people.

The form of the story as well as its interpretation and its conclusion, given by Nuruddin $\mathrm{Ab}$. dul Rahman Jami, is much closer to the popular interpretation currently common among the peo- ture is highly expected.

It is hoped that further research and discoveries be carried out by the scholars, about the presence of the same-story or anything similar to it in the works of other poets and men of letters. Similarly a comparison of popular stories in the comonm language with their presentation by famous men of poetry and litera-

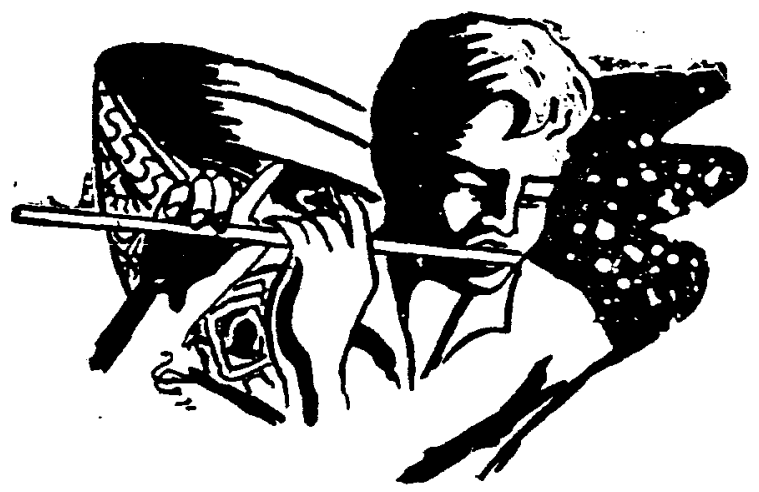




\section{The Orphan Boy}

Edited by Reshad Wasa

Translated into Engiish

Abdul Haq

Along time ago, an orphan boy used to live in a hut with his mother.

For years, they lived from hand to mouth. one day, his mother sold his father's chisel and saw, telling the boy "Sonny, you are now coming of age. Take this money and do business with it. "The boy took the money and left the hut He saw a man in the bazaar selling a cat. The boy paid him the money and returned home with the cat. On seeing the pet she was flabbergasted, saying "We can hardly feed two mouths. How could we feed this cat?"

After a few days, she sold her late husband's shoes and gave him the money, saying "Sonny, take this money and buy something better with it." The boy took the money, went to the bazar and came across a man who had brought a dog for sale. He bought the dog with the money and returned home with his new aquisition. She was non-plussed, saying "Sonny, was the cat not enough?"

After a few days, the mother sold her old rug-her last possession- and gave it to her son, saying 'Sonny, this is our last hope as nothing else is left in the house. Take this and buy something better. "He took the money and went to the bazaar where he met a man selling a snake with a painted crown. The boy bought it with the money and returned home. His mother was frightened at seeing the snake, saying "Sonny, the cat you brought is chasing the mice. Your dog guards the hut. What did you bring this sanke for? Take it out as soon as possible and kill it with a rock."

The boy took the snake out The snake told him "Oh kindhearted boy, don,t kill me because I am the son of the king of snakes. My father has got lots of rubies and other jewels. Above all, he has got a huge gleaming ruby which he values most. $\mathrm{He}$ always carries this in his mouth. Ask him to give you this. Whoever takes possession of this ruby, all his wishes are fulfilled"

The boy took the snake to his father's court. The king was 
frightfully delighted to see his son back He told the orphan he would give him anything in reward The orphan replied he would,nt ask for anything. The king said he would be delighted to do something for him. Then the boy asked for the jewel the king was carrying in his mouth. The king said he could not fulfil this wish. He should however, ask for something else.

The boy stated he did not have another wish and left the court.

The king's son told his father the boy had saved his life and the king did not want to part with a jewel. So he was also leaving:

The king now realized he was losing his son. So he told him he was giving the jewel to the boy who had saved the life of his son. Thus he called the orphan boy back and handed him the jewel.

When the boy came home, he found his mother starving Addressing the jewel, he said "we want food clothes and hous." No sooner had he opened his eyes than he saw new clothese on himself and his mother while their old hut was changed into a mansion with georgeous foods on their table-cloth.

The boy lived comfortably with his mother. The king of that domain had a beautiful dauhter with whom the boy had fallen in love. Once the hoy asked his mother to go ani ask her hand in marriage with niw: His mother said he was the son if a carpenter and he king would nut consent to this union. He replied that he could provide anything the $\mathrm{ki}$ ng would ask for. So his mother went to the king tocomply with her son's wishes. The king thought she must be crazy. In order not to hurt her feelings, he said her son should built a palace with gold and silver bricks covering its floors.

The mother brought the message to her son. At night, the boy told the jewle he wanted to have a palace with gold and silver bricks.

At dawn, the people in the surrounding area saw in front of the royal palace another with gold and silver bricks. On seeing this, the king was impressed by this enormous wealth and gave his daughter in marriage to the boy. The orphan lived happily in this palace with his beautiful wife, his old mother and the cat and dog.

The boy loved to hunt. Every day he rode his stallion and went to the plain for shooting. There lived in this area an extremely vicious old witch one day, she dug a grave on the way to the plain. When the bay was returing home he saw the old womean screaming near the grave, saying she had just lost her only son and had nobody to turn to.

The kind-hearted boy told him to stop screaming and co- 
and live with him. The wiwiped her crocodile tears ndwent along with the boy.

Time went by. One day, when the boy had gone hunting, the old witch asked the princess where had her husband got ill this wealth from?

The princess told her that her husband had a jewel fulfilling all his wishes. Then she told the princess to ask for the jewel. This would be test to measure his love for his wife, she expastulated.

When the boy returned home, the princees asked him to give her the jewel if he really loved her. The boy said he loved her more than all the treasures in the world put together. However, she must guard the jewel very carefully.

One night, when all were asleep, the old witch stole the key, opened the pricess's jewel box and took possession of the ruby Then she told it she wanten that palace to disappear and the carpenter's wife and the princess banished in remote towns. When the boy woke up, he did not see a sign of the palace, nor of his mother and wife. Only his cat and dog were there. Very depressed, he went to the plain, with his cat and dog following him. They travelled day and night, hungry and thirsty. They passed through many towns till the boy was too tired to walk. But the cat and dog continued the search for the jewel Finally, they arrived in a place where
...........4 The Orphan boy arrangements were being made for the wedding of the son of the king of rats. The cat lept and caught the would-be bridegroom telling him unless his father's subjects found the jewel, he would not free him.

Thousands of rats scurried everywhere till a lame one found the abode of the old witch. She was asleep with the jewel in her mouth gleaming. The rat sprinkles some snuff on his tail, brining it near her nostrills She sneezed and the jewel was thrown out of her mouth. The rat lept, took the jewel and hid in a hole in the wall. The old witch raised hell but to no avail.

The rat brought the jewel and the cat released the rat prince. The wedding began and the cat and dog continued their travel taking the jewel. They came across a wide river on their way. The dog gave the cat a ride on his back as the latter was holding the jewel in his mouth. While swimming, the cat noticed a fish and jumped to catch it. The jewel fell off his mouth into the river. The dog was furious and admonished the cat severely Hoever, they watched the fishermen day in and day out to see if they could trace the jewel. One day, the cat saw a fisherman catching a fish whose skin was gleaming She realized it had swallowed what they were after.

The cat lept to catch the fish. In a flash, he ripped it 



itit: $:$

open and took the jewel out. him stories about their unhap This time, the dog held the py days. Then he asked the jewel in his mouth and ran as old witch, who was also there. fast as he could with the cat whether she wanted a whip following. The boy was nearly or a horse. She said naturally dying. Delighted to see his she wanted a horse. Then the faithful cat and dog, he told boy tied her with the horse's the jewel to recreate the palace tail and whipped the horse to with his wife and mother in dragher on the plain.

it. In a glimpse, he found himself with them in the same palace. They kissed one another and shed a few tears of joy.

His wife and mother told

Thus he got rid of the old witch and lived in his palace with his wife, mother, faithful cat and dog happily thereafter.

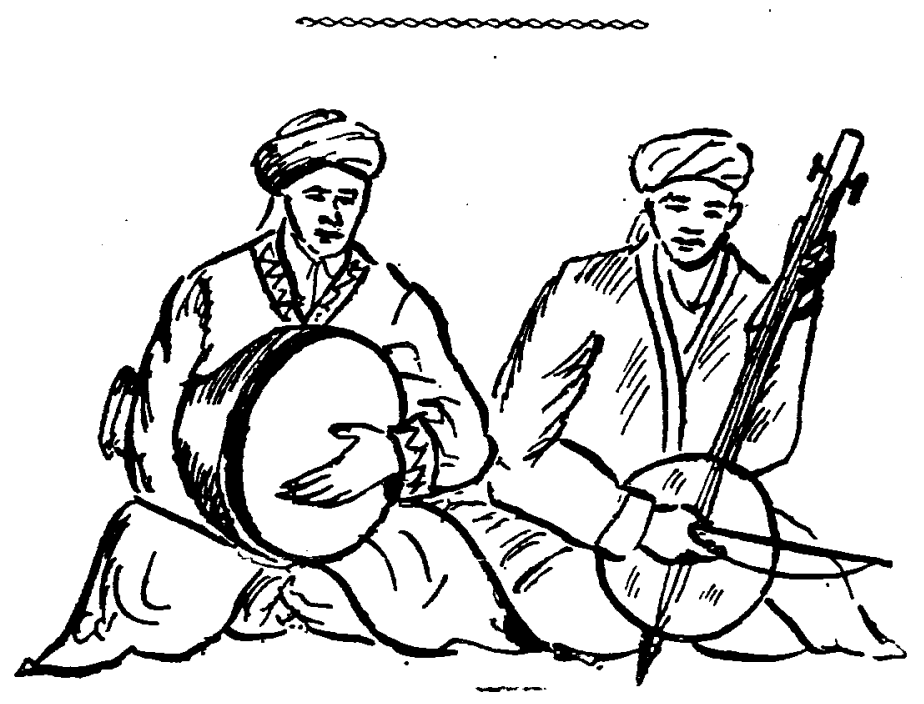




\title{
Birds Animals and
}

\section{Folk ideas}

\author{
By Andishmand \\ Translated by Abdul Wadood
}

The purpose of this essay is to investigate to folk ideas of the afghan people, even if not to provide entertainment.

The people of Herat find the sound and movement of birds and animals pleasureable. As long as they can hear and see. These sound and movement expect a good future.

\section{SWALLOW:}

Sowallow which is called (Ghochi) in Kabul, and (Frestrock) in Herat is beloved by every one. The people allow the swallow to make nests on the ceiling of their rooms. And after allowing them to build the nests the people leave some opening in the house, as that the birds can come and go as they please.

Also people believe that swallows sing (Alam Nashra) (religeous song) or verses. So the people believe that annoying them is a great sin.

There is another folk idea among the people that if they take swallow to their rooms and they colour one of the swallow's wings with suffron or curry, the swallow will return in the following year and bring a present for them.

\section{...THE AFGHAN PEOPLE ALSO HAVE FOLK IDEAS about (Bats)}

There was a folk idea among the people that good quality diamonds could be found with the help of bats. The idea was that, immediately after the bat gives birth to babies, someone should take the babies away from the nest, and place them beneath a glass, or something made of glass, and wait untill the mother attempts to recover them.

According to the legend, she will try to do so by breaking the glass with a diamond she has taken from a mine. Also according to the legend the diamond she uses will be the most valuble in the world. The bat is also famouse for (Shapark-i-Charmee) among the people.

THERE IS ALSQ A FOLK IDEA

ABOUT PIGEON AMONG THE PEOPLE.

There is a belief about the pigeon, specially about the white dove that has agreement with fairys. A few people find usefull to have one or two pairs of doves with them.

On the other hand, they think it wouldn't be any good to hunt and eat the meat of dove. 
They say anyone who consumers the meat of dove, will become either ill or insane.

Also, they say the ringdove shouldn't be killed, because, they believe that the neck had been ringed red by the blood of the martyrs.

\section{CROW:}

The crow, famous in Herat by the name of (kolagh), appears in the sky during the winter. The people understand its cawing to mean "snow" "snow" and believe that it is this cawing which actually brings on the snow.

\section{PARTRIGE:}

The partrige's eye is thought always to be salty and therefore cause bad luck to every beautiful thing it looks upon.

\section{MAGPIE}

There is a long-tailed bird, colored black and white which, according to Afghan folk ideas, is usually a carrier of good news, especially from travelers back to them loved ones and families. Whatever or not its message is good can be determined by looking at how it sits. If it sits facing Mecca, the news it brings certainly good.

The legend further says that, should a woman see the bird in such a position, she can discover what the good message is by addressing the bird this way:

"Oh happy messenger, your bill is full of sugar. If you have good news for me caw once." ... ACCORDING TO AFGHAN FOLKLORE, IF A COCK

crows untimely, for instance during the night ,it must be killed immediately or else* its owner will die.
The some must be done to any hen which crows, whenever she does it, because if she is allowed to lives some unwholesome event will take place in the house of her owner. Another folk idea about the hen is that whenever she lays a double-yolked egg. some people will have bad luc and others will have good luck.

Also should a hen crow as she is laying an egg, Afghan folklore says her crowing "(kot, kotkota)" means, "I have given birth to a baby with no hands and no feet." And also, when a ringdove sings it says that" ko, ko, ko.

Yosif jo.

Tass az tou. (Bowl for you) Mahs az mha. (Yogert for me) Bagh az tou. (Garden for you). Taq az mha (Shelf for me)

And turle-dove says "Mussah! ko nafasi"

\section{..THE AFGHAN PEOPLE ALS0 HAVE FOLK IDEAS ABOUT "CAT"}

The tongue of the cat, according to legend, is made out of diamonds and whatever is licked by her is therefore clean, and shoudn't be washed, if the hair of a cat should fall in food and be eaten, it is thought that the person who eats it will get a disease (Azar-i-Moraq)

Owners of houses can tell wether they will have guests by watching their cats.

When the cats sit opposite the door and lick their hands and face, the guests will soon arrive. It is further thought that cats are capable of enduring any kind of pain, even torture, and that to kill one for certain. 


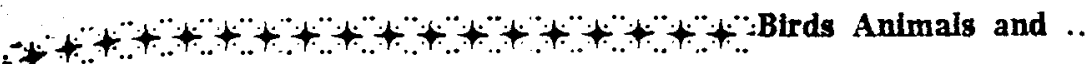

one must kill it seven times THERE ARE ALSO FOLK IDEAS because it is believed all cats ABOUT MANY OTHER ANIwave seven lives. However, the MALS'

person who does kill the cat will himself pay the consequences andness.

THERE ARE ALSO LEGENDS CONCERNING dogs.

For example, the howling of doss, famous by the name of

concerning mice, it is thought that the food they have touched shouldn't be eaten and that the presence of many mice in a house means there is also a traitor there.

Asses are believed sometimes When a dog is observed to lie on his back with his legs in the air, legend takes it as a symbol of a caffin and a sign that there will be a death in the family of the dog's owner.

mar) on the fingers can be cured, according to legend, by putting the wounded finger in the asses ear.

ACCORDING to tradition white cocks should be killed on the Eve of the New Year.

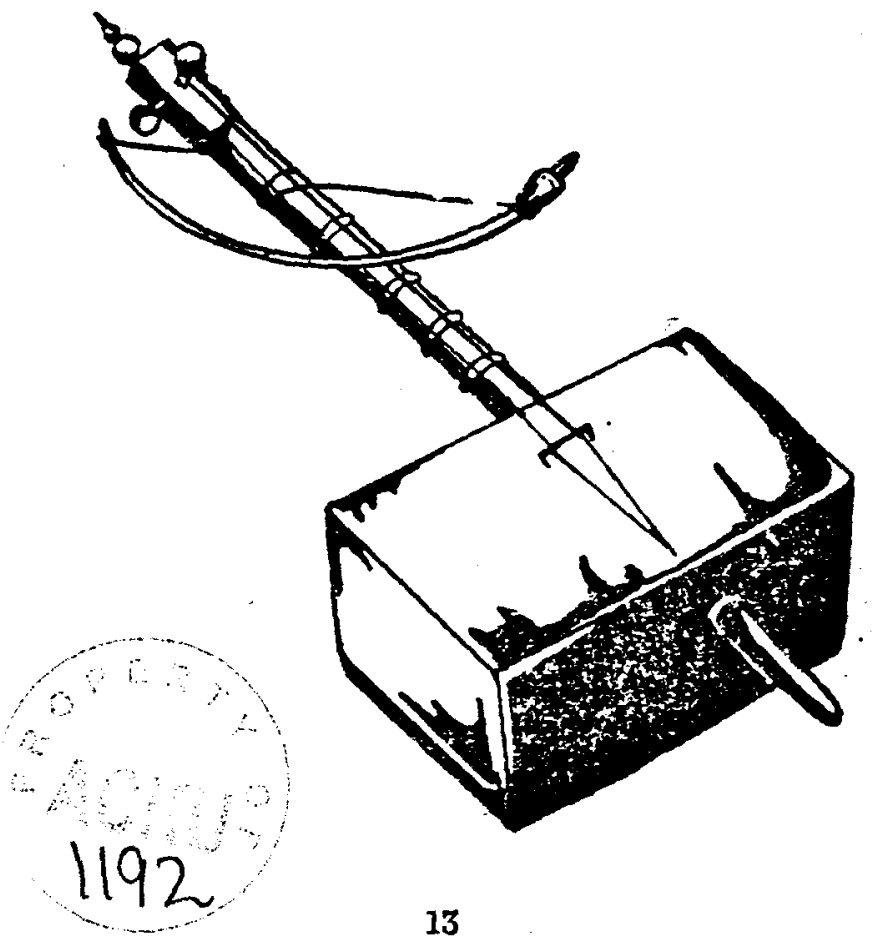




\title{
The Story of A poor prince
}

\author{
by Sabzikra \\ By Mahria, Adel \\ Translated, by Sabzikar
}

Once there was a king. He had three sons. One day the king summoned his sons to tell them that he had reached to the end of his life and he might die soon. "Therefore", he said. "I have a behest for you that after my death one of you in turn should come on my grave every night and pray there till the morning. His sons accepted his advice. One day the king fell dead. They burried him with honour. At night the youngest of the three suggests that their elder brother should fulfill his fathers behest for the first night But the eldest brother asked the second one who in his turn rejected and finally the youngest brother had to go and sit on his father's grave for the first night. He sat there till the morning and prayed for his father's soul.

On the the second evening the youngest brother asked his two elder brothers that one of them should do the job. But again they both rejected. And so they did on the third evening and the young fellow had to remain on the grave. On the third night there were hausted and tired. They pitched lots of wind, thunder and lightin-their tent and fell asleep. ing. Suddenly a fearfully big giant appeared and roared: I smell the smell of a human being. Where ever you may be. I shall eat you. The boy hid behind the grave of his father. He then suddenly jumped and grabbed the gient by his hair. They say that a gient can do nothing. When he is caught in the hair. So he sur. rendered and swore that he would not harm the body. The giant said, "I swear in the gem of solomon that I'll do you nothing but help." He released the giant but the giant, in apprciation of his relief, gave three threads of his hair to the boy and said." take these hairs of mine. When ever you are in a difficulty, just burn one of them and I'll immediately appear before you." Saying this she disappeared.

The other two sons of the deseased king were very idle and aimless men. In a short time they ruined all the works of the land. So the people dismissed them and appointed another king. The three brothers left their city to go some where else. After travelling long distances they reached that other city ex- 
Now in this city the king had orree beautiful daughters. These inds had proclaimed that each of them would marry a man who could fulfill their conditions. The conditions was that any man askin the hand of a princess in marriage should climb on horse back the fourty stairs leading to tower and beat the drum on the tower. Then he should climb down the stairs on his horse beck to their palace. It is only then that the princes would agree to marry him. The three sons of the first king who were in this city then, heard about it. The two elder brothers put on their best clothes and rode their horses to take part in the competition. It was here when they heard that the king had said, "Any body taking part in the competition would be hanged if failed in the competition. The two brothers saw that every competitor could climb only ten or fifteen steps and would fall back and meet his fate. They also saw the bodies of several young people hanged. So they did not dare to take part in the competition.

The younger brother told his brothers one day that he intended to go for the competition. But his brother laughed at him and mocked him. They said, "First of all you do not possess the right kind of clothes. Secondly you don't have a horse. How can you ever take part in a big game like this." Then they left the house and their young brother. after finishing his works and cooking the meal the young prince took it of the gian,s hairs and burnt it. Suddenly a horse appeared before him loaded with very beautiful clothes. The horse stopped when he reached near the young prince. He took the clothes and put them on, combed his hair and rode the horse away towards the competition ground. When he reached there, the people thought that a prince from an other city had come. They gave him way. He rode the horse straight towards the steps, climbed it up to the last one, beat the drum, came back and went. His brothers did not recognize him. When thes came home, he had already put out his clothes, had put them on the horse back who had gone the way had come. The young prince had put his old clothes and was seated near the fire place before his brothers came. When they arrived at home he asked them about who had won the competition. They answered, "Don't ask! A young prince climbed up the stairs in one charge, beat the drum and returned to the ground." The prince said, "I wish I had come with you." His brothers laughed at him again and mocked him. On the second day the two brothers went again to watch the game without taking their younger brother with them. The young boy burnt another hair and immediately a red horse with brown clothes on his saddle appeared He put them on, rode the horse and off he trotted towards the field.

The time again he climbed the stairs on his horse back, beat the drum and came back successfully. Again he rushed home before his brothers, took 
the new clothes out, put them on the horse back and send the horse away. When his brothers came home he was waiting for them with his old clothes on. They were very upset and angry and said that another prince had won the second competition that day. The young brother begged, "Take me with you just for once. May be I could win the race with God's help." His brothers laughed at him and said," Many wellknown persons failed to win the race, how could you possibly win it. On the third again the two brothers went to the competition ground without taking their brother with them. The young and poor prince took the third giant's hair and burned it. A brown horse with brown suit on him appeared. Again he rode him and won the race like the previous days. This time the young prince went to his broth. ers with all his dignity and charm and told them the whole story. They were very ashamed of their behaviour toward their brother. They apologized and promised to behave themselves, better in fu. ture.

In the town there was the rumour that the King's daughters were going to marry the three brothers who successively won the competitions. The three brothers went to the palace The king accepted them and each brother married with one of the king's three daughters. Each one of them built a castle of their own. God accepted their wishes. May he also accept ours.

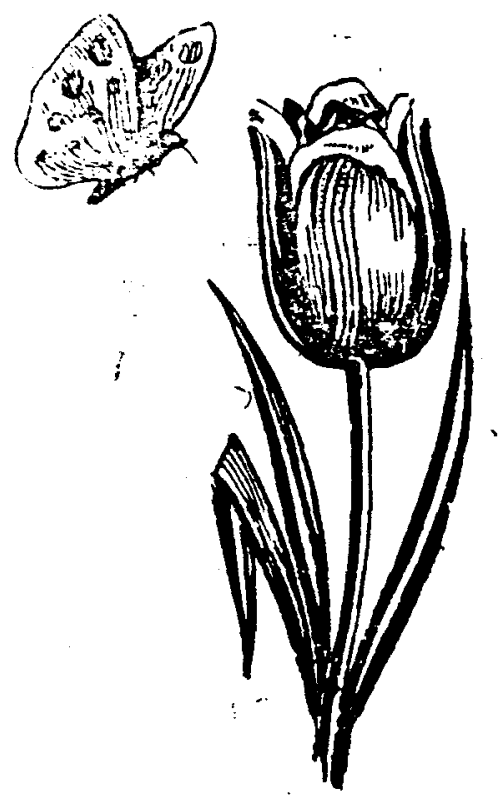




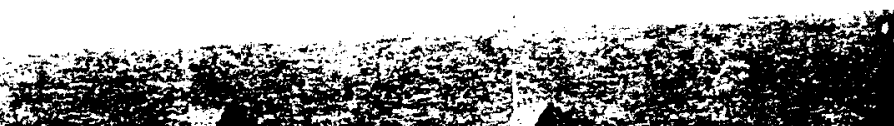

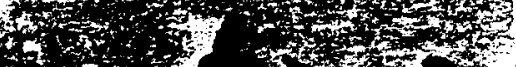
Writs

\section{S.. 30}

$\lim _{i \rightarrow \infty}$

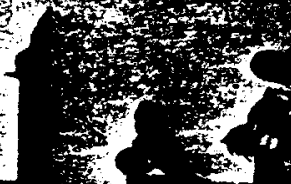

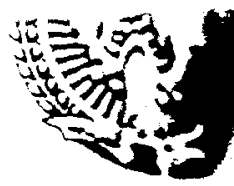
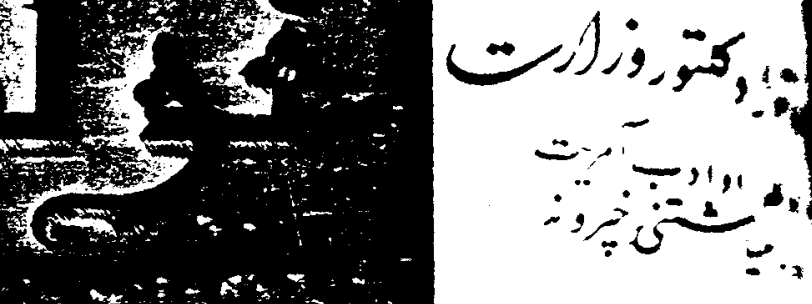



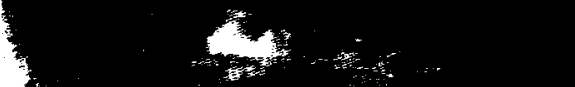

a

1)



*

*

$1+2$

3

t?

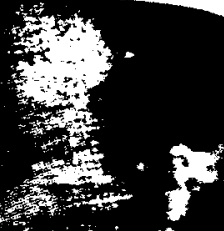

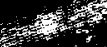

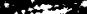

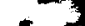
3 it सी th

$$
\text { }
$$

Pf
4
4
4 3
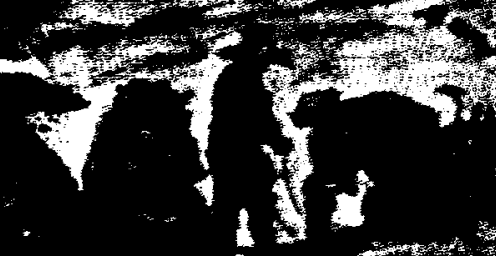

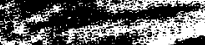
tist

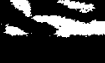

(1)

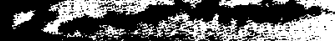

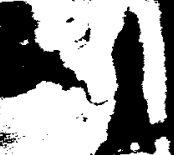

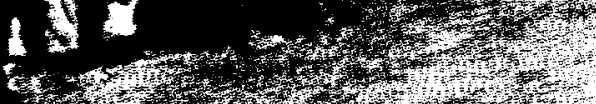

(n)

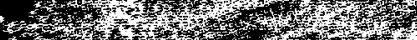


W.t. tom the कs

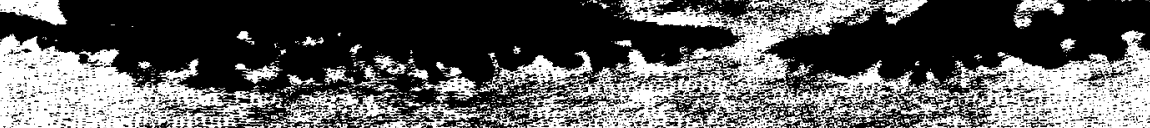

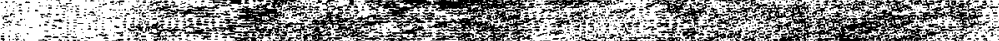

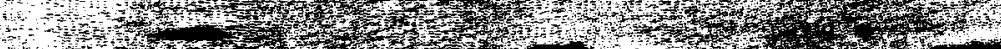

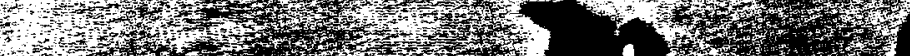

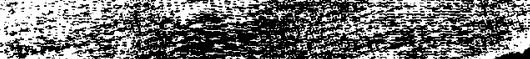

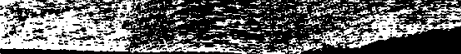
in. $47 x^{2}+x^{2}$ 4.5. $x^{2}+2 x+3$




Folklore Department's bi_monthly

VOL . 2. NO. 2-3, ACGU - NOV, 1974

\section{Editor: Nessar Ahmad Behin}

Head of ed:torial board: S. N. Kulali.

EDITORIAI, BOARD :

1. Nusullah Sahraii.

2. M. H. Nazihi.

3. S. Maascom Sharifi.

4. Reshad Wasa

Assist:nt editor: Zohra Chopan

Tel: 26653 Editor.s 20451-3-Ext. 48

Annual Subscription:

Kabul :Afs. 70

Provinces: Afs. 80.

Abroad: $\$ 6$.

One Issue: Afs. 15.
Folklore Department's bank account: 6001 .

Subscription rate may be paid cash in Editor's Office.

Address: Ministry of Information and Culture, Kabul, Afghanistan.

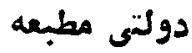

كاس : محمد هاشم عباسيى 
by $\mathrm{N}$. Sahraii

\section{Love in Traditional Folk literature}

Rafq Jan Kaftar amad Kaftar alities of a girl. Like this one: umad,

Vajiba dokhlari sawdagar amad, Delam mekhwast Najiba ra begirom,

Najiba na morad shoydar baramad.

Some times a quatrain reflects the easy thinking of a certain people in connection with finding a partner. In the above Du-baiti a fellow meets a girl, snddenly faIls in love with her and hopes to marry her bit soon finds out that she is engaged. So he expresses his emotions like this:

O'Friend, a pegion came, a peg. ion came,

Najiba, the merchants daughter has been here, her,

My heart wished me to marry

But the hopeless Najabiba turned out to be engaged.

Certain quatrains indicate the taste of a man concerning the beauty, the colour and other qu-
Zamin khoub ast Zamin-i khina khoub ast,

Meyani mewaha kangina khoub ast,

Meyani mewaha angouri shii in,

Meyani dukhtara sabzina khouh ast.

. Translation:

The ground is good but in the colour of hena,

Among the fruit kangina is the best,

Among the fruit the sweet grapes.

Among the girls a tanned colour is best.

Kangina is a clay compact larger than a plate in size.

It is especially made to reserve grapes inside of it for the winter season. Although by explaining a small fact about this gr. ape reserving compact we may slip aside from the actual theme, yet it is worthwile since it explains an important aspect of people's life particularly those hav- 
ing vine yards producing grapes.

The people of kohdaman, the famous area for grape harvests keep a certain amount of their product in Kangina for the winter use when fresh fruit is rare but most wanted by the people. The grapes keep well in it and sells for high prices in winter but the interesting point is another aspect of it which relates to folk medication. Sometimes the grapes inside the clay compact dacay partly and produces a sort of mould. This mould is given, as a doze of medicine to patients suffering from fever or other deseases.

Musulmana delam gham dara emroz,

$\mathrm{Ba}$ mesli lala shaknam (shabnam) dara emroz,

Jegarem khoun delakem para para,

Ke yarem mayli raftan dara emroz,

O'Muslems, my heart is full of pains today,

Like a tulip it has frost in it, My lever is bleeding, my heart is torn to pieces,

Because my fiancee intends to leave today.

This is something unusual. A young fellaw, or may be an old fellaw, who knows?, admits that he has two fiencees, he is in live with two girls at the same time:

Du yar darum yaki mah o degar roz,

yaki dukhtar degar Arous-i seh roz,

Shuda deri ke royeshan nadidum;
Ze eshq-i hardu mesozum sh. ab o roz.

I have two fiancees, one shines like moon and the other is bright as day,

One is a virgin, the other a th. ree day's bride,

But since long. I have not seen their faces.

I'm burning in the love of bo. th of them.

Namak shour ast ba zakhmi ta. za nandaz,

Mara kushti ba shahr awaza na. ndaz,

Mara kushti ba dasti khud ka. fan $\mathrm{ku}$,

Ba dasti mardum-i begana na. ndaz,

The salt is sour, don't put it on a fresh wound,

You have killed me, don't ru. mour in the city,

You have killed me, shroud me with your own hand,

Don't let me in the hands of strangers. .

As a by the way recommendation I would like to reexamine the correctness of a love song's interpretation published in the issue No. VI of Folklore page 2, 3 .

This beautifully composed quatrain of Takhar province:

Ee dokhtari bafinda ra yaresh bashum,

Abreishumi Qirmezi-i taresh bashum,

Makou-i brenji merawad shast ba shast,

Manandi nawarda dar kenaresh bashum. 
Bears a more romantic and sensible meaning than the very shallow and easy interpretation given to it which is considered incorrect by many. The narrator of the quatrain says:

I wish to be a friend I of this weaving girl,

I wish to be the crimson silk in her yarn,

The brass shuttle goes from one hand to an other,

Like a bolt of cloth $I$ wish to lie beside her.

The above quatrain is an expression of an ideal, a wish, and not the story of a person with his wishes already fulfilled.

In the third verse the way a shuttle moves to and fro, from one hand to another is rejected as a mean thing. It does not explain the warm and tender love affair.

It is worth mentioning that in most folk songs in the form of quatrains, the third verse is usually either the rejection of any thing said in the second verse or the rejection of any idea whether mentioned earlier or not. It may as well belittle the second verse and show it less important. Like these ones:

Ajab nalano sargadanum imroz, Meyani atashi suzanum imroz, Meyani atashi suzan che basha, Farari mulki Turkistanum imroz,

How much moaning and anxious I am today,

I am amongst a burning fire today,
What is it to be amongst a burning fire,

I am banished to, the country of Turkistan today.

In the third verse of the above quatrain the expression is that, what importance it has or what difference it makes to be amongst a burning fire, because, as in the 4th verse, I am banished to Turkistan which is much worse than being in the fire.

Or,

Agar ahi kasham De-naw besozad,

Muradkhani o Shahri-Naw besozad,

Murad khani o Shahri-Nau che bashad,

Deli yarem da jayi khaw besozad.

If I sigh, De-Naw will burn,

Muradkhani and Shahri-Naw will burn,

What is Muradkhani and Shahri-Naw?

The heart of $\mathrm{my}$ girl friend will burn while she is in bed.

Here again the third verse shows the least importance of Muradkhani and Shahri Naw (two residential quaters of Kabul) in comparison to the burning of a heart.

Therefore in the quatrain concerning the weaving girl the attractive sense of the poem is in its purity of love free from ordinary love affairs.

It is rather interesting to see that like all other communities, our folk too seems to have persons with unfavourable motherin-laws. Like a cartoonist, the lover in the following Dubaiti (a 
girl in this case) addresses her mother-in-law:

Ala khushoo beshin bala i tandor,

Ma atesh mekonum chashmat shawad kor,

Agar az khater i bachet nabasha,

Begirum dasteta partum da tandor.

O'mother-in-law, sit down near the ovan,

I'll make a fire, may your eyes become blind,

Were it not for the sake of your son,

I would have held your hand to push you into the ovan.

The girl hates her mother-inlaw but for the sake of her son whom she loves as a husband imparts with the idea of pushing her to the ovan to burn.

Anar i Tashqurghan (1) seb i Samarkand,

Judaii yarakem bekhi mara kand,

Har ankasi oura az man juda kard,

Da ateshha besoza mesli espand.

Translation:

Tashqurghan's pomegranate, Samarkand's apple,

Dearture of friend has urooted my foundation,
Whoever has separated from me, pand.

May he burn in fires like is

Espand or esfand is an aeroma tic seed, dark brown in colour and triangular in shape, widely used by people all over the coun. try to avoid evil eye by putting it on fire.

Ze eshqat mekonam faryad, faryad,

ke dada haselam barbad, bar. bad,

guzashtam man shabi az khaki sherin,

shunidam nalahi Farhad Far. had.

In your love I cry and cry,

This love has destroyed my life,

I passed by the grave of Sherin one night.

I heard the cries of Farhad, Farhad (2).

As a whole love occupies a high place in the lives of all folks despite its consequences. Sometimes love is expressed for things other than beauty. ove for the country, for God, for the people, for religion etc. has always been shown which will be discussed probably some other time.
(1) A county in northern part of Afghanistan famous for its fruit.
(2) Sherin and Farhad are he ros of an ancient love story frequently mentioned in all early literature and poetry. 
BY MOHD. HUSSEIN YAMIN

Translated into English by A.H.W.

\section{Dari Folk Literature in}

\section{Parwan}

Literature is, in a way, the means to recognize realities through. One of its main characteristics is to reflect the mass of social, scientific, political and religious ideas of a nation in a particular time. Therefore, iiterature is called a full-length mirror depicting all aspects of iife of a nation as it is a manifestation of the changes that constantly take place, along with the consequent wishes and desires, mirth and happiness, pains and tortures as well as social disappointments and frustrations.

In fact, literature on the one hand enriches the language and a rich tongue is equipped to express every concept or idea; on the other, the language itself constitutes the essential material for literature. Hence the more developed a language, the richer its literature. And the more sublime the literature, the more limited the number of its users. Yet samples of sublime literature are the best introduction to a nation. For ins- tance, the works of Chekhov, Dostoyóvsky and Gorky picture for us Russian society of the time as much as those of Shakespeare, Dickens and Bronte reflect British way of life and those of Molliere, Balzak and Emile Zola mirror the lives led by the French. Likewise, folk literature which originates in human societies, depicts real life of a particular people at a given time. Also, this type of literature is considered a record of the people's lives. Therefore, folk literature occupies a place of importance beside formal "belle lettres". Actually, the former emanating from the majority of the population reveal more vividly that particular people's characteristics, customs, traditions, tastes and other qualities as this type of literature originates in society and dates back to the antiquities.

Folk literature is transmitted from father to son and enriched after each generation as a result of social changes. It opens its way in society beside other forms 
of literary endeavours. It has indeed occupied its rightful place in our society in recent years. For quite sometime now, some of our authors produce valuable essays, articles and pamphlets, introducing our folk literature. Thus they are shedding light on one aspect of Dari letters, paving the road for others.

With the above considerations, the writer began to do some research on folk literature in Parwan as a step to help preserve this part of literature which is a source of cultural accomplishment and pride.

\section{PROVERBS}

A proverb is known as "matal" in Parwan province which lies to the north of Kabul. Each of these symbolizes years of experience and wisdom till the precise thought or idea conveyed is chrystalized and polished to make the necessary impression on the person in question. Hence, in case someone fails to win an argument despite lots of logical reasoning, he has to resorts to the suitable proverb. Some of these are literary gems produced by important literary figures of the past.

Many proverbs are in daily current in Parwan. However, it would be impossible as well as inappropriate to separate proverbs being used in Parwan from those in vogue in other parts of the country because the whole body of folk literature belongs to the entire nation. But proverbs must be preserved anyhow; at any cost. Collecting all the proverbs in question may take a long time but this will be done in the future. The proverbs presented below contain educational, critical and social thoughts:

Educational Proverbs

1-"Don't tear your collar before dying." This is almost equivalent to "Think before you leap".

2-"Don't take off your boots before seeing water." This means haste makes waste.

3-"Be in rags, but be clean. This means cleanliness does not ncessarily go hand in hand with means.

4- "Half a bread but comfort." This means one could be conten. ted with little but far more comfortable than those who are ag. ed by hard work caused through greed.

5-"Stretch your legs as far as your rug extends." This means you have to be careful not to overstep your authority or capabilties.

6-"Fill your palm with flour but use your finger when it comes to cooking oil." This means you have to be economical otherwise you will finish everything sooner than expected.

7-"Don't absorb the moisture like a damp wall." This means don't have a chip on your shoulder.

8- "You do unto me what I do unto you." This means "you scratch my back and I scratch yours."

9 -"Where is the village and where are the trees?" This means something is out of place as the trees are expected to be seen in or around the village where en- 
ough water can be had and not elsewhere.

10 - "The money obtained from milk goes to milk and that obtained from water goes to water." This proverb has originated after someone has observed a crafty milk maid mixing water with the milk in order to increase its volume and income. After sometime, the maid has fallen ill and spent all her savings on medication.

11-“A crazy needs a slight gesture." This means not to provoke such men.

12-"Sit slanted but tell the truth." This means no matter how you sit or walk so long as you tell the truth.

13-"The well-fed cannot realize the feelings of the hungry and the man riding a horse does not understand the fatigue of a pedestrian. This means one should not be callous.

14-Don't crow untimely like some cocks." This means don't drop any bricks. Actually, a few years ago, lots of hemp plans grew in Mohammad Agha, Logar, in a wild state. Since the chickens in that area as well as elsewhere were left to - fend for themselves for food, they picked the hemp seeds and this somehow confused their sense of timing. So they crowed at all hours.

15-"A lop-sided load wont reach its destination." This means when you base your actions on deceipt, you would not get anywhere.

16-"If they even sell a camel for a stick. "This means you have to have some money in order to afford something. For instance, if some one sells a camel, which has always been a very expensive animal, for a stick or a song, and you don't happen to have it, you won't be able to purchase the animal.

17- "Truth is everlasting." This means you will come to no harm if you keep on telling the truth.

18-"A buttonholer tears a deaf man's ear." This means very talkative people even get over a deaf man's nerves.

10 - "Poison is for that who fails." This means you will have to do the most undesirable things when pushed hard.

20- "Don't add a plume to his hat." This means don't flatter him in order to use or exploit him.

21-"I have got my tooth pulled off." This means he is no mo re interested or he has washed his hands off it.

22- "You can't come out from the flour mill without some flour dust on you." This means you cannot cover up indications or evidences.

23- "One cannot be a blacksmith by blackening one's nose. "This means you have to first master the tricks of the trade and then claim proficiency in it.

24-"Fraternty calls for equality". This means you cannot claim any privileges when it co- 
mes to hard facts in life.

25-"A donkey lagging behind another should have its ear snapped." This means in a fair competition, everybody should do his best to win the race.

26-"A butcher cheats the customer he knows best." This means be careful not to trust those with whom you are familiar only on business terms.

27-"He can pull out his donkey from the mud." This means he can get or pull along.

28- "A dead man's personal efects should follow him." This means his clothes and such likes should be given away in charity for his salvation.

II- Social Proverbs.

"Leave the town but not violate its prices".

This proverb is used in many cases, especially in buying and selling. It is also employed in case someon attempts to violate a social convention.

"You have to take turns even in your father's flour mill."

This proverb obviously teaches order and discipline in social life.

"Look at my pale complexion and not inquire after my health."

This proverb says there is no need to make inquiries when the case is so obvious.

"Catch the flying ones, the crawling ones will be there."

This implies that one should always consider one's list of priorities.

"The dead goes only to one place while the living have to go to hundred.
This shows all sorts of probl. ems people are faced with after the head of the family passes away.

"He is shroud for the dead and cloak for the living."

This indicates someone useful in all times.

"Watching my belongings, I retain my wits."

This denotes the care you take of your personal effects pays you well.

"When you are drowned, no matter how deep."

This proverb is used in two cases. First, in a financial sense, when you are in debt, secondly, in a moral sense, when somebody is degraded.

"The hole is there, but not the weaver."

In old days, those who used to weave cloth had to sit in holes where they operated their primitive looms with their hands and feet. The above proverb says the indications are there, but not the person in question.

"Shut the door and all the evils with it."

This means take your safety precautions and rest assured that everything will be all right.

"Stretch your legs as far as your rug".

This means one can be safe by not overstepping one's authority.

"The person who can afford eats kebab, the other only inhales its odour."

This means don't be tempted to buy anything unless you have got the money for it. 
"If the whole world is enundated with water, it won't affect the ducks".

This proverb is used in the case of those who are not affected by the events and don't care ab. out others.

"To the tired, only a step means something, to the thirsty only a drop."

This proverb is used in two senses. First, it is almost an equivalent of the English adage, "The last straw broke the camel's back". Secondly, it means one can help the tired or the thirsty so easily if one has some feelings.

"What does the blind want? A pair of seeing eyes."

This proverb is used when one's sole desire is fulfilled. Forinstance, if he wants to have a son and the son is born, he is likened to a blind man who can see now.

The thief has got a plume on his top."

This proverb must have been coined by a lay psychologist. It is said something precious was stolen and all the suspects were collected. The interrogator who thought crossexamining each suspect would take a long time said the thief had a plume on his top and the person who had committed the theft felt his top and was immediately caught.

There exists another proverb meaning the same thing. It says "the thief's cap is on fire". The third one, "The thief cannot be nccommodated in a mountain" means he is caught, sooner or later. nd."

"You cannot clap with one ha-

This means you cannot achieve anything worthwhile alone unless you join hands with others.

"A stream is formed by accumulating drops."

This emphasizes the importance of economy.

"The crazy knows what is good fri, him".

This means nobody needs another's help when it comes to his own good.

"While my hands are busy, my eyebrow is itching."

This is used when you are preoccupied and another thing of urgency crops up.

"Borrowing a copper bowl from a bear."

This is employed when somebody asks a miser for credit.

"He is looking for things belonging to the dead."

This is used in the case of those looking for things to buy dirt cheap.

"You will be appreciated when you are dead or far away."

This is used in the case of close relatives or neighbours not appreciated when alive or living near-by.

"If you have eaten the yoghurt, the container is there". 
This means there is always an indication of what has been done.

"He has one head and a thousand worries."

This means he is terribly busy and cannot concentrate on a single thing.

"When the water comes up to the neck, one stands on one's own offspring."

This is used when someone does something out of desperation.

"Cut the melon according to the size of the man."

This proverb teaches sense of proportion.

"The new servant catches the galloping deer."

This means those who are newly employed show much enthusiasm in their work in the beginning to catch the eyes of their bosses.

"A handful of grains represents a ton."

This sampling is generalised in social cases too and consequently wrong conclusions are reached.

"One hundred persons cannot take care of one while one can take care of one hundred."

This means every body is not an able administrator. Only one in a hundred is bestowed with the talent and skills required.

"It is easy for the old to die but this opens the death's door."

This means one should not allow the evil to start.
"The best thing in the worn day."

This means if one has got ion. ething valuable, it can be easily disposed of when one is hardpressed for cash.

"The bad thing belongs to its owner."

This means one should take care not to buy cheap things oth. erwise one will be stuck with them. In other words, one cannot get rid of worthless things even if one tries.

"When the reaper does not want to work, he sharpens his sickle with lumps of earth."

This is an equivalent of the English adage, "A bad workman quarrels with his tools."

"There is no saltiness left in salt."

This means nobody nowada's remembers having eaten bread and salt with someone.

"Let have bread and salt."

This means let us eat something to become friends. It is used in almost the same sense is in English.

"To ride on a donkey's back underneath someone's same beard."

This means to deceive somebody in such an obvious way.

"God may not extinguish his larap."

This means he should be sur' ived by a son. 
"He has no blade of grass on the ground and no star in the skj."

This means he has got no beans.

"When you are a bachelor, you eat the whole bread."

This means your expenses pile up when you are married.

"His hoe is moving underneath the soil".

This means he is so sneaky. Another proverb says. "He is crawling underneath the mat."

"The son is not born yet but he has already got a name."

This means one should not jump to conclusion.

"When a calf becomes a heifer, the farmer's wife pines away."

This means one have to be patient in order to achieve something.

III-Critical Proverbs.

"Too many butchers spoiled the bull."

This is an equivalent of "Too many cooks spoiled the broth."

"Beat the dog to teach its owner a lesson."

This implies an indirect punishment as the proverb indicates.

"The river could not be fouled up by a dog drinking water."

This is an equivalent of barking at the moon.

"The eyelashes become too long when one is eathing."

This means one ignores or overlooks other while eating otherwise he has to ask them to par. take his food.
"The stomach is not turned in to meat."

This means you cannot change the nature of things.

"I did not touch the porrige but the smoke blinded my eyes."

This proverb is used when someone is troubled about something he has not enjoyed.

"The winter ends while the charcoal is left with its black face."

This means the trouble will soon be over but those who have not been of any help shall be ashamed of themselves.

"The more you remember winter, the more it spells cold."

This means unpleasant events or things should be mentioned only once.

"The dead donkey had a goldembroydered coat."

This is used when someone loses something worthless he has borrowed and its owner exaggerates in its value to get a higher compensation for it.

"The donkey's tail is one foot."

This means whatever reasons you put forward, the obstinate would'nt budge. There is also another proverb saying, "His cockhas got only one leg."

"I only remember you, it is God who may satisfy you."

This teaches the people not to be greedy when presented with a gift. In other words, dont lock at the teeth of a gift horse.

"Sitting beside me and plucking my beard." 
This means one should not say nasty things to a person in his face either about himself or his close relatives. ot."

" He puts both feet in one bo-

This is used in the case of obdurate persons who don't listen to reason.

"Selling the birds in the sky dirt cheap."

This means to deceive people with hollow words.

"He neither eats it himself nor gives it to someone else but feeds the dog."

This proverb is used in the case of misers.

"His hand cannot reach the plum and says they are sour."

This is an equivalent of "The grapes are sour."

"The goat is worried about his life and the butcher about his fat."

This shows how two person's interests differ. In other words, what is good for gander is no good for goose.

"He squeezes himself into one's eyes with his clothese on."

This means he denies such an obvious fact.

"One sieve taunted the other because of its holes."

This means when one has a particular defect, he should'nt tease another because of it.

"How could a frog skate?"

This is used in the case of someone who is not qualified for a particular job.
There is also another proverb, "To catch quails with crows."

"Making so much noise and laying only one egg."

The meaning of the above is obvious.

"You make your noise here but lay your egg elsewhere."

This is used in the case of someone who causes trouble in your place but his profits are pocketted by someone else in another place.

"The son-in-law is older than his father-in-law."

This indicates lack of propurtions. There is also a another proverb, "The culvert is larger than the orchard."

"Why don't you spell it out and say 'peach".

This means don't beat around the bush.

"He is like a mule."

This means he is ungrateful, and not obstinate( as used in the west:

"Marriage is an easy job to a spectator."

This means the person who does not pay the expenses can inake lots of suggestions.

"A little strength and a lot of -fuss."

This is used in the case of $30^{-}$ meone who does not accomplish much but brags a lot.

"Hot water is the best punishment for dried yoghurt."

This is an equivalent of "tit for tat". 
"His mind is in the fourth skJ."

This means he is La Lune.

"He uses lumps of earth stepping stones."

This means he only thinks about the present or he is so superfluous.

"Play with anything but not with your grandfather's beard."

This means one has to take certain things dead serious.

"One cannot become a blacksmith by blackening one's face."

This means for every profession you need certain skills. Or the apparence alone does not count
"The old cow dreams about cotton-seed cakes.".

This means one is tempted ofas ten by things unaccessable.

"I entered through the door and he went out through the window."

This shows how eagerly one avoids another person.

"He avoided the leaking roof but sat under the rain."

This means his condition went from bad to worse. $O r$ in his attempt to escape trouble, he got more of it.

"He has prepared youghurt in his spade." 


\section{By Sabzikar}

\section{The Story of a Fairy}

Once there was a laundry man. He used to take the clothes down to the river to wash them. After washing them in indigo and ironing them, he would load them on his mule and take them back to his customers.

One day be placed the clothes on a big stone. He washed each item separately, hitting them with a stcik. After he loaded the clothes on his mule to take back to his laundry shop, he saw a soft, white fur on the riverbank. It was as white as the snow. He picked it up thinking that he could make some. thing out of it, but he could not because the fur was too small. Anyhow, he took the fur back to his house and dropped it in an unused comer of his storeroom, forgetting all about it.

The next morning when he awoke he noticed that the yard, the kitchen and all the rooms in his house were clean and orderly. He was surprised to see this because it was the first time his house was so neat. When he asked the rest of his family about it, no one had done it. The next day same thing happened again, without his family participating in the cleaning. $\mathrm{He}$ thought that he had to find out who was doing the cleaning.
One day he woke up early in the morning and hid in a corner of the house. To his surpri. se a very beautiful girl came out of the storeroom with her head wrapped in a white scarf. and she started to sprinkle water on the dirt and sweep the yard. When she finished her work and wanted to re-enter the storeroom, the laundry man approached her and caught her arm. He asked her, "who are you? where have you come from? Why do you help us like this?" The girl tried hard to es. cape but was caught up too tightly; he told her that he would not release her unless she told the truth. The girl replied that she was actually a fairy and that her hiding place was in that rabbit fur. She said, "Since you picked the fur from the ground and placed it in a better place, I wanted to help you." The laundry man told her that he would nat let her leave now that she had come to his house. He said, "Since I have no children, I want to adopt you as my daughter and keep you as my own child." The girl accepted his proposal and stayed at the house.

Now, the prince was also one of his customers and the laund- 


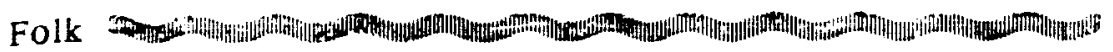

ry man would, every day, wash and iron his clothes and send them back to the prince's house. One day when putting on his clothes, the prince found a long, golden hair on his shirt. The colour of the hair attracted him so much that he thought of finding its owner. In his mind he imagined a very beautiful girl, judging only from that single hair. He went to the launddry man's house and saw. the girl through the window. He noticed that she was as beautiful as he had imagined. $\mathrm{He}$ summoned the laundry man and told him that he wanted to marry his daughter. At first the laundry man refused to tell the truth: he said that he did not have a girl worthy of a prince. However, when the prince insisted, he was obliged to tell the truth, that he had just adopted a young girl as his daughter. The prince convinced the laundry man; and both the prince and the girl got married.

After the wedding ceremonies when the prince was going to his bedroom the prince's nu'se called him to ask him something but he did not hear her. The nurse was annoyed and said, "You have only married the daughter of a laundry man and have become so proud that you don't answer me. What would you be like if you had married a princess?" Hearing this the prince became indignant and refused to go to his bride, he even refused to see her face. Many days passed without the prince going to his wife.
The fairy was very upset and disappointed until her mother (who was also a fairy) came one day and asked her how she was. The fairy told her the entire story. The mother advised her, "When the prince comes tonight ask him where he is going the next morning. Wherever he is going, you arrive there and somehow show your face to him" That night the girl asked the prince where he was going the next morning and the prince said that he was going to the Yell in Gerrinn.

The following morning the girl put on a beautiful lemon coloured dress and went to the garden. When the prince arrived there the girl passed by him and saluted him. Upon seeing her, the prince fell in love with the girl without recognizing her as his wife.

On another day the girl again asked the prince where he was going the next morning. The prince answered that he was going to the Green Garden. In the morning the girl put on a beautiful green dress and arrived at the garden before the prince. Again she passed in front of him and said hello. The prince recognized her as the same girl he had seen the previous day, but she seem. ed to be prettier this day. The prince invited her for a short walk but she simply smiled and proceeded along her way.

On the third day when the girl asked the prince where he was going the next day, the pr- 
The story

ince mentioned the Red Garden. At the particular moment, the prince asked his wife to bring him a glass of water. The girl brought the glass of water but dropped it as soon as it touched the prince's fingers. She picked up the broken pieces of glass but she cut ber finger and it bled. Although, as usual, the prince did not look at her face, he took out of his pocket his handkerchief and bandged her finger.

In the morning, the girl, wearing red clothes, reached the garden before the prince. Again she

passed in front of him and said hello. The prince noticed that finger was bandaged with his ow handkerchief! He asked her wh ere she got the handkerchief and she replied that it was the ame one with which he had bandaged her finger the night before. The prince was surprised to discover that the beautiful fairy was no one else but his own wife. He regretted what he had done rery much and blamed himself for not looking at his wife at least once. He apologized to her and both proceeded towards their palace to restart their happy lives. 











(inistry of Information and

Culture

ji-Monthly Magazine published by the Afghan Folklore Department.

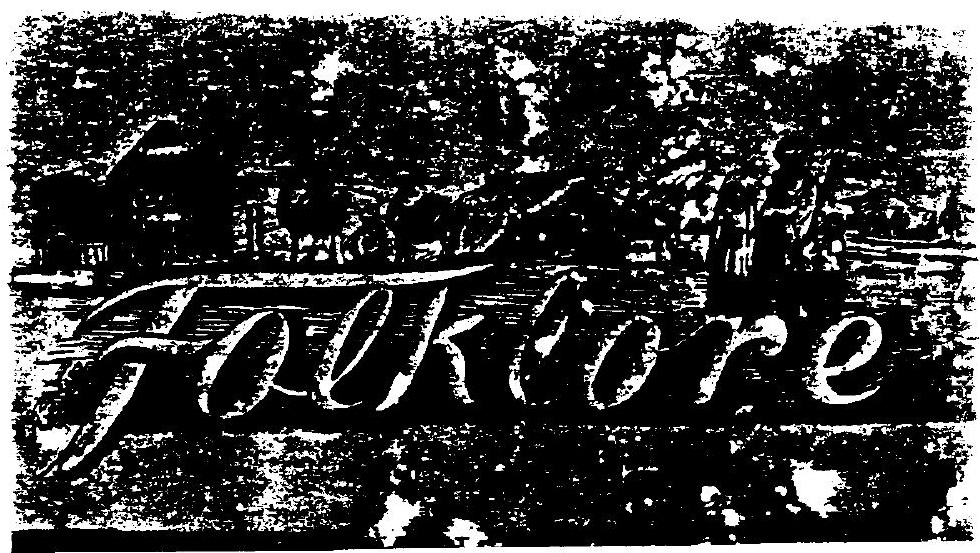

CONTENTS: (Dari and Pashto parts)

Title :

Autho:

Page

1. The Common Culture

2. The fields of Folklore Studies

S. N. Kulali

$1-4$

3. Folk Medical Treatment

Poya

$5--14$

t. Foiklore Studies

5. Hrmoneals in Zurmoli, Paktia Province.

b. Kabu: has rich and valuable Folklore

7. Folkloric Chess

Translater Dy Darna 15-22

Nessar : Behtin

$23-28$

M. Maasooum

$29-35$

Hamed Husseini

$36-43$

H. Rafee

$44-50$

8. Traditional games

M. N. Wasel

$51-54$

2. The past fate

P. $\mathrm{H}$.

$55-59$

10. The Moghul girl

11. What could be this?

Poya

$60-73$

12. Dari Folk Literature of Parwan

Ali Mohammad

$74-77$

H. Yamin

$78-84$

\section{ARTICLES IN ENGLISH}

1. Jove in the traditional folk literature "

2. Folkways of the Zadrans

Nanawatay

3 Parwan Folkways

Nurullah Sahraii

$1-4$

Transiated by A.H. Waleh

A. H. Waleh

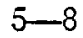

$9-17$

Back page: The old man seen on work repairs the shoes. 
Folklore Department's bLmonthly

VOL . 2 . NO. 1, MAY - JULY, 1974

\section{Editor: Nessar Ahmad Behin}

Head of editorial board: S. N. Kulali.

\section{EDITORIAL BOARD:}

1. Nurullah Sahraii.

2. M. H. Nazihi.

3. S. Maasoom Sharifi.

4. Reshad Wasa

Assistant editor: Zohra Chopan

Tel : 26653

Editor's: 20451- Ext.38

Annual Subscription:

Kabul : Afs. 70

Folklore Department's bank

Provinces: Afs. 80.

Abroad: \$ 6 . account: 6001 .

Subscription rate may be paid

One Issue: Afs. 15.

Address: Ministry of Information and Culture, Kabul, Afghanistan.

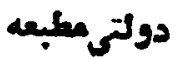


by Nurullah Sahraii,

\section{Love in the traditional folk Literature}

Rich and overwhelmingly orientated with all kinds of verbal delicacies and flavoured with all spices of social life, the common people's languages and dialects spoken in Afghanistan form the most important part of the people's literature.

Having a history as old as 5000 years or so, the land of the Aryana, due to its geographical advantages. has always been an outstanding crossroads of all cultures and civilizations and resembled a flower-bed where different sorts of florae from various regions and climates were planted, and grew up, some times changing colours and shapes due to the very natural processes of insemination and genetic developments. The very popular proverb "Kharbuza Kharbuza ra deeda rang megira wa hamsaya hamsarara deeda pand." is a plain indicator of this fact. It means

The mellon, by seeing an other mellon adopts its colour and a neighbour by seeing an other neighbour takes a lesson (an advice).

It is a scientific reality that
Hlowers adopt the colurs of one an other if grown near each other which is of course the result of nacural insemination helped either by the wind or by butterflies. This is the secret of life and development, the secret of being and continuity.

Love has always been and will alviays be the spirit of life and literature in all societies and among men of all stages of development from the primitive communal society to the most advanced ones today. And love to the opposite sex has always been and will always be the greatest of all loves in the universe. I wonder if it was love which beautified the nature or whether it was the beauty of nature that created love.. but what ever the case may be. love and beauty have always been togeher. I donot really know how wide a frontier exists between love and sex or whether any such frontier exists between them at all. But I know that the beleifs and considerations in this connection cover a wide range of variations all over the world. In this country the countless beanty spots 


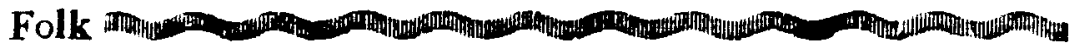

and picturesque sceneries with $a$ mild and fragrant cimate in the spring have witnessed through centuries many adventurous, romantic and great loves; some of them universally preserved in the memories in the form of stories, lyrics and songs.

The stories are often told in family circles usually for entertainment while the songs are aften heard every where in the country side if you are there early in the morning. A young donkey rider with a turban on the head, paizars as foot-wear and earth-colour (khaki) clothes of ten sings some of the very sentimental love songs sometimes accompanying it with a flute at dawn when most of the people are still asleep even in the country side. This donkey rider may not necessarily be in love but he relates the hardships and troubles caused by love to the hardships of his painstaking life and the cruelties of his arbar, malik or Khan who has for years exploited him and all his family members. Or may be he is in love with the damsel of the fellaw farmer who is pressed by the land owner or by the malik (Chief of the village) to give his daughter to himself. Otherwise, in normal cases, all love songs and love stories common among the common folk tell about faithfulness, loyalty, jealousy, affection, departure, perseverance, truth and honesty in love.

In this brief article I would like to cut short the margenal explanation $_{S}$ and give some examples of the most popular lyric poems from different parts of the country instead. This could be self-explanatory and saves extra writings on the subject. A translation of course, and some analysis of the poems are also given to facilitate the digestion of the rather unfamilier style for the foreign reader:

Asheq nashawi ke Asheqi bad bakht ast,

Gahi bebini gah nabini sakht ast.

Don't fall in love, because love is a bad luck,

Sometimes you may see (your beloved) sometimes not, It is hard,

Love has always been considered a most difficult and dangerous thing in life yet every body has been some how involved in it having accepted all its dangers and hardships. It is even considered as bad luck, seen from the above Robaii, two verses of which are missing.

$\because *$

Bya ke berawim azin welayat man o tu,

Tu dasti mara begir o man daman i tu,

Jayi berasim ke hardu bemar shawim,

Tu az gham i bekasi o man az gham-i-tu.

Let us go out of this province, you and I

You take my hand and I take your skirt.

We may reach a place where we both get sick,

You from the pain of loneliness and I from your pain.

In this Rubaii the lovers are disgusted by the traditional limits and restrictions of their society. 


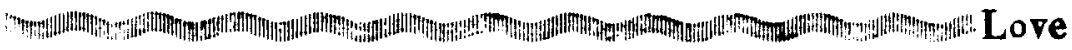

Therefore the young lover is determined to escape a suffocating society. He asks his fiencee to make an escape with him although he knows for sure that in solitude they will both get sick and tired, yet he prefers that to a suffocating environment.

Yaran o beradäran mara yad koneid,

Taboot-i mara ze choubi shamshad koneid,

Taboot-i mara qadam qadam bardareid.

Dar khak-i seyah baneid o far. yad koneid.

Fed up with the hardships of life, mainly caused by failure in love, the narrator of this Rubaii expresses his intention to die and address his friends:

$O^{\prime}$ friends and brothers, remember me,

Make my coffin from the pine wood,

Carry my coffin step by step,

Put it in dark soil and lament on it.

The above Rubaiis are from the well known style of Quatrains popular in most parts of the country and carrying different names in different places. For example they are called Falak in Takhar, Sang-gardi in Panjsher, Robaii in Kabul and Charbaiti in other places. It seems that this style of poems has become popular in Afghanistan after the introduction of Arab culture and literature.

Another style of folk poems which is more widely popular in all parts of the country is the well-known Du-baiti or Charbaj- ti. These poems, the originality of which is not clear as far as the time is concerned, are widely sung by nearly everybody irrespective of age and sex.

Dubaitis are full of sympathy. love, affection, complaint, and packed with explantory terms and words about cruelties of time. depressions, despair, hope and struggle. They often reflect a most sincere and sometimes a sort of platonic love otherwise more realistically mixed with the every body's life in the every day's activities. Unvoluntarily and irregularly spread as these poems are all among the folk, I would like to quote and translate them in the same manner.

Examples:

Man az kocha gozashtum khanda kardi,

Mara ba khali syahit banda kardi,

Nadanesti tu razi asheqi ra

Khoda raswa mara sharminda kardi,

I passed through the lane and you laughed,

You enslaved me with your dark spot (on the cheeck or forehead).

You did not realise the secret of love,

You revealed my secret and made me ashamed.

Mahi dar begira ee zamana,

Kasi ba yari khoud gashta natana.

Mahi bachai shaitan bemira, ke ahwal mebara khana da khana,

Pray to god that this world be burnt-No one can walk with his fiancee, May the son of satan 
(1) die, He reports from house to house.

Ma qurbanet shawom ay pesta dandan,

Namedanom ke turki ya ke Afghan,

Aga yak show da pahloem koni khow,

Fedayet meshawom man az del o jan:

May I be sacrificed for your pistachio teeth.

I don't know whether you are Turk or Afghan.

If you sleep next to me one night,

I'll sacrifice myself to you from the bottom of my heart.

Ba dastat Jami Aw basha $E:-1 i$ man,

Jamalat mahi naw basha gui, man,

Amu sa'at ke az khana baraii Delam peshat graw basha guli man.

You have a cup of water in hand, O'my flower,

Your face is like the moon, $O^{\prime}$ my flower,

The moment you leave your house,

You ravish my heart O'my flower.

(To be continued)
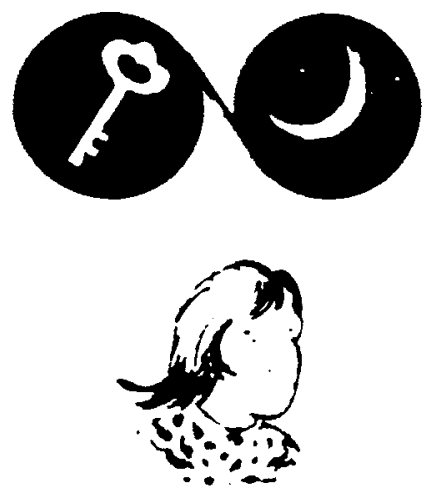

(1) Shaitan or satan which means the devil is always used to imply the spy or a back-biter in the common language. 


\section{By Laal Padshah \\ Translated by A. H. W. \\ Folkways of the Zadrans \\ Nanawatay}

\section{GEOGRAPHICAL LOCATION}

Zadran is a mountaiuons area in Paktya province, bounded on the east by the so-called Durand Line, on the west by Gardez, Zormat and Sarrouza, on the northeast by Mangal and Khost and on the south by Orgoon and Berma!.

There are two valleys located on the bank of a stream, one known as Tangi and the other as Shemal.

According to a sensus taken a long time ago, the maie population in Zadran numbered 9,000 as all females are not counted beca. use they do not play equal roles with males.

The area forms an administrative district subdivided into six units as follows: Khawak, Bodgay, Zerok, Dingay, Gavani and Nader Shah Kot.

The Shemal Valley adicins Gardez and Khost while the Tangi Valley is adjacent to Khost and Orgoon on the other-side of which are located the Wazir in $\mathrm{Pa}$ shtunistan area.

ECONOMIC, SOCIAL AND POLITICAL CONDITIONS

Local economy is still in its feudal form. If a hamlet consisting of two families is locate in a da$l e$, all the natural resources such as the land, the forest and the pastures are shared equally by both. However, one of these plays a more dominant role due to the fa- ct that it has more memberz. In other words, power is based and excercised on sheer number of persons capable of fighting and overwhelming the other side.

Since most of Paktya is mountainous and one valley is cut off from another by a high and sometimes forbidding mount in, not only a mixed economy has not been developed but also the inhabitants of each valley have been able to preserve their iolkways. This makes the whole province unique and extremely rich, culturally.

The subject of this ariscle is to deal with "nanawatay" in Afghanistan in general and in Paktya (and more so in Zadran) in particular. For instance, nanawatay is prevalent in Ghazni, Zabul and Kandahar in its ancient form as a tradition. If someone kills another or a man runs away with somebody's daughter, this is either avenged personally or settled through nanawatay. For instance, the family of the man who has killed another or the household of the boy who has run away wi:h a girl is joined by religious leaders, poets or elders of some repute to pay compensation to the family that has been wronged.

In Jalalabad, Laghraan and Kunar elderly man and people of consequence join the nanawalay dicputation in Kunar women walking with the 
deputation hold copies of the Koran oputation hold copias of the Koran some wheat along. In Paktya, ca. rrying wheat is not prevaient. One of the elderiy members of the deputation says to the family which has been wronged "Whot the Pashtuns do is to make war and make war again. And you know what comes next? They have to make peace, eventually.'

NANAWATAY RULES IN ZEROK

Nanawatos is resorted to in several cases but the idea behind the whole practice is to make ap ologies and find out how could the family that has committed wr ong make amends. In case the family at fault does not resort to nanawatay, it is admonished, at least verbally, by members of the community who think it is asking for more trouble.

\section{NANAWATAY IN THE CAST. OF MANSLADGHTER}

If someone kills another by mistake or through accident, his family appeals to the bereaved bousehold to pardon the culprit because there was no criminal intent involved. The bereaved family may impose a fine either in cash or kind on the family of the culprit. But no nanawates is acceptable in the case of murder. Only when the bereaved family is too weak or short of fightins men, it may agree to nanawatas. In this case, many bulls and sbeep are slaughtered near a mosques or inside compounds and the man in charge of the culprit's family ws ually ties a rope around his neck, places a burning wood inside a pot on top of bis head and holds some grass in his mouth symbolizing his total submission to the bereaved family. In some cases when nanawatay becomes more serious, the mullahs and lehwajas hold copies of the Koran on top of their heads. In ather cases when the bereaved family shows much resistence, the man in charge of the culprit's family stands or sits inside the grave dug for the person just killed and asks the bereaved family to bury him there instead of the dead man.

The compensation for the murder consists of a few bulls and sheep, some money and three marriageable girls who have already been engaged to others. Except the animals which are acceptable on a large scele, other parts of ho compensation are generally returned ensation are generally rcturned. In case a oereared family may accept the girls and the money in addition to the bulls and sheep, people in the neighbouhood may comment upon this that "they are selling their deads. "Consequently, this undermines the standing and reputation of the hereaved family and thus its remaining members would not be able to deal with others on an equal footing.

Since the feud between two families may yead to antagonism between two clans and in some cases, between two tribes, counter-compensation is demanded at the rates and prices fixed by a group of intermediaries known as "marakchians" whn are sometimes replaced by local influentials. In certain cases, the compen- 
sation or counter-compensation is demanded in cash.

The consequences of the compensation in kind are too grave to be imagined in the outset. For instance, when a sister or daughter of the person who has killed another is married to a brother or son of the killed, other members of the bereaved family may treat her disdainfully and this mas spoil her life. In case she cannot stand it any longer, she may either commit suicide or run away either with another man or to her own family which worsens the situation.

In case the compensation consisty of one or more girls from another family or clan, as selected by the bereaved family or its supporters, then the family of the culprit has to pay the breaved family or clan some money as dowry. However, the number of girls given in marriage or the amriunt of money paid in cash vary from one tribe or place to another. Sometimes even a single woman given in marriage is considered sufficient.

NANAWATAY IN THE CASE OF DEFAMATION

If a young man from nne family defames a female from another. all the male members of the girl's family turn against him So $h_{e}$ also resorts to nanawatay but to no avail. He is therefore sent to coventry. The fact that nanawatay is not accepted is due to the nature of the Pashtuns that does not lend itself to defamation or contemptuous treatment.

For instancce, if a man from one family blocks the way for a girl from another and tries to make passes at her, men from the girl's family would do the same to a female from that man's household. The treatment is exactly tit for tat. If the girl ivas forcibly kissed, which is an extreme offence, the men from the other family may kiss a girl from the man's. If her scarf was thrown away, the men from the girl's family do the same to the girl from the man's.

In this case, nanawatay comes after "eye for an eye" treatment. So the family of the man who had blocked the way for a girl from another household takes a number of sheep or goats to the family of the defamed girl to slay. This is then reciprocated by the girl's family because it has already avenged itself.

In case a man fires a few shots in the air on seeing an unengaged girl and then tells everybody that she belongs to him, the man's family has to resort to nanawatay or be prepared for a perpetual enmity on the part of the girl's family. Usually the influentials choose their sponses this way. However, the man has to give in marriage a girl from his own family to someone - like the girl's brother.

In case a man tries to get fresh with a girl, members of the girl's family first pay him in the same coins and then agree to a nanawatay. If the girl's family is contented with the nanawatay and does not want to accept the conrpensation in the form of a girl given in marriage, 3 sheep and Afs. 3,000 would suffice to settle the score.

Meanwhile, the marakchiars 
have it all made because both pa-compound of a saint's mausolium rties compete in feeding them as best they could, as long as the matter is settled. This may take Three or more days inerhaps sometes the intermediaries willingly $\mathrm{pr}$ olong the negotiations to wallcw in the hospitality.

The marakchians also charge set fees for their peace-making services, ranging from Afs. 1,000 to 3,000 per person. This helps them make a living because they specialise in this profession and know how to settle matters of life and death

In case a man runs away a gi$r l$, he leaves an incriminating $\mathrm{ev}$. idence. like a piece of his clothes in the house so that the girl's family resort to the same act or similar to it like getting fresh with the girl from the man's family or blocking her way and then agrees to Eanawatay.

One form of nanawatay is holding the leg of the dead man's bedstead on the part of the cul. prit who beseeches members of the bereared family in order to pardon him on behalf of the deceased for the wrong done.

In other cases, the culprit sits in the grave freshly dug for the person killed in an accident involving this man. If this nanawatay is accepted by the bereaved family he is asked to get out of the grave. otherwise he is forced out and avenged personally on the part of the bereaved family.

In case a family oppresses another, and then the oppressor re. alises the wrong done. it takes a few sheep or goats and slays them near mosque or inside the and then sends the meat to the house of the village eleder to be cooked. When all the important people in the village are asker there for lunch or dinner, as the case may be, one of them ques. tions the owner of the house as to the reason behind the feast. Ue explains the case whereupon the elederly request the man in charge of the oppressed family to accept the nanawatay.

In the case of a dispute on land or other possessions, both parties transfer their authorities to two men who represent their $1 n^{*}$. ersts and speak on their behalf. sometimes talking for days till they reach a settlement. This may or may not be accepted by one or both parties in which case the score is settled through a fight.

In the case of a fight, the par ty which has won the day but realised that it was all a mistake and the others did not deserve so much beating, follow the same procedure as the oppressor fami. ly with the exception that it has to pay some cash for medical tr. eatment of the wounded. Further. skins of the sheep slain on the occasion of nanawatay are also given to the wounded in order to cover their bodies with to get a traditional care.

Often the family which has su. ffered does not agree to the nanawatay and hence avenges itseif personaly by giving a tit for a tat. However. the family may wait for a long time till it gains the required manpower and strength to beat the hell out of its opponents. 


\section{Parwan Folkways}

\section{CUSTOMS}

Customs in Parwan province differ from one place to another according to ethnic groups. For instance, customs in Panjsher are different from those prevalent in Tagab or Surkhe Parsa or Kohband. In the latter place, the inhabitants speak in Pashaye. However, what is described below is valid in the case of the majority.

Also there are differences in degrees, and emphasis as far as the same customs in various families are concerned. For instance, in a rich family, many rites are observed in child-birth while most of them are forgone in a poor household.

\section{CHILD BIRTH}

When a baby, preferably a boy, is born in a rich family, usually the local barber or in his absence, one of the close relatives of the family makes a round of all families somehow related to that of the boy on the third day of his birth, announcing the name of the child and distributing sweets at the same time. The baby is given his or her name usually by the grandfather or the local elderman or the "mullah".

Of course prior to child-birth and afterwards, the mother's close female relatives or neighbours help her in the process and later in handling the baby, cleaning the house, cooking and entertaining the guests. Mostly, the mo- ther's sisters or those of her husband are of a great belp on such occasions till the mother musters enough strength to stand on her own feet and be able to take care of her own family.

In each village, usually there is an "old witch"-an experienced elderly woman who performs the duties of a midwife without any legal authorisation or set fees and other old women may prescribe medicines in case the baby or her mother falls sick.

Also, usually on the third day of the child-birth, the baby is either taken to his or her grandfather in order to shout the "azan" into his or her ears or the grandfather is asked into the house. In case the grandfathtr excuses himself, the job is carried out by the local mullah.

Previously, mothers were not allowed to play an active role in giving their children their desired names. That was why mothers in protest started giving their children nicknames or titles which gradually submerged the real names. However, now a few mothers enjoy the upper hand in this connection, but in most cases they imitate the city folks. When, for instance. Pashtu names are in vogue in Kabul. the mothers in Parwan villages follow suit. Otherwise. when they see a nice chubby baby and like him or her, they pick his or her name, as the 
Folk

case may be

As soon as a baby is born, a religious old woman gives him or her a bath and applies antimony powder to his or her eyes. Should the grandfather (s) have lost one or more grandchild in infancy, they obtain for the new baby talismans from the local mullah or the professional magic man which are covered, according to the instructions of the writer,with leather, silver or cloth covers, and hung around the neck of the child.

In case the baby is chubby and handsome, the family provides him or her with a special talisman to avert the evil eye.

The baby is dressed, from child-birth till he or she starts walking, with a special garment known as "sherwani" and "qalandari" and a headgear called "gosh poshak". However this dress slightly differs with the type of the baby's bedstead. In other words, it largely depends on whether the baby sleeps in a cradle or in a swing.

But in both cases, the baby's hands and feet are tied tightly inside his or her garments which is wound around with a canvas strip. The headgear is adorned with silver ormamentst and coloured beeds and sometimes with a coloured plume but this is often put on his or her head when the baby is walked by someone and is not in the bed.

ENGAGEMENT

When a boy reaches the age of puberty, and his family is rich, arrangements are made to get him a finace. In some families where customs are still all powerful, and where the new Marriage Law has made no impact, boys and girls are engaged by their parents in their infancy. For instance, a brcther or a friend gives his daughter in marriage to the son of his brother or friend and in return gets his consent for the marriage of his son to his brother's or friend's daughter. This is a kind of barter known as "badalakan" which means "an exchange".

The economic aspect plays an important part in badalakan because one family does not and cannot impose much expenses on the other knowing that the other may resort to a reciprocal treatment. However, the main drawback of this sort of marriage, apart from it's intrinsic shortcoming, is that in case one husband mistreats his wife. his sister who is married to his wife's brother is bound to suffer in revenge, at no fanlt of hers.

In case the boy's family is not rich enough, first his sister or sisters are given in marriage and the money charged on them in cash go into the marriage expenses of the son or sons. The amount of money ranges from Afs. 20,000 to Afs. 50,000 , depending on the beauty and skills of the girl. The cash is known as "toyana' of which in average Afs. 50000 is spent on the girl's equipment (Jehez) and the rest is deposited, usually with a trustworthy shopkeeper to be utilised later to meet the marriage expenses of a son. The girl's family insists that should it not charge the boy's family any toyana at all. 
IIVI)

the girl would not be appreciated by her in-laws because nothing free is valued.

To send a few men or women to the girl's house to ask her hand in marriage is necessary whether the boy and girl have already met and liked each other or not. They repeat this trip a few times because the girl's family dillay dallys despite the fact that it is in agreement to the marriage. Each of these men or women is called an "afsaqal" which means "a man with a white beard". The act is known as "afsaqali" while the consent of the girl's family is known as "lafz". Girls who do not wait for afsaqals because of being too passionately in love with their chosen men enter the houses be longing to their future husbands and refuse to leave here intill married. However, this kind of elopement is looked down upon and such girls are taunted for the rest of their lives, especially by their sisters-in-law.

Usually, a few female relatives of the boy's family are sent to the girl's house for afsaqali. Then comes the time when this should be followed up by a few men. These comprize the father or grandfather of the ruy aud usually include one of their important relatives. After the lafz is given, the girl's close relative or an elderman presents thte importanit afsaqual with a sugar cune, a handkerchief and a pound or two of "nuql", the Afghan sweets consisting of sugar-coated nuts. Should the girl's family be rich enough, each of the men is given the same, otherwise they only receive a few sweets.

The last afsaquali is formulated a sa rite. For instance. the head afsaqal asks his opposite number: "Sir, do you know what we have come here for?"

He feigns no knowledge of the whole thing and says he does not have any idea.

Then the head afsaqal breaks the important news, saying: "We are here to ask the hand of Miss Ayesh a (for instance) in marriage. with Shamsuddin, should Malik Dean Mohammad accept him as his slave.

Malik Dean Mohammad either does not budge or just nods positively while the head counter-afsaqal does all the talking, saying Malik Dean Mohammad accepts Shamsuddin as his son-in-law and gives Miss Ayesha to him in marriage.

Afterwards, the local mullah or elderman prays for the happiness of the future couple and they leave for the boy's house in good spirits, taking the sugar cone, efc.

In most cases, the cash as well as other marriage expenses are determined when lafz is given. For instance, the head counter-afsaqal asks the boy's father for Afs. 20,000 in cash, two sheep, 20 "seers" of rice 30 seers of flour and amounts of vegetable oil, etc. He insists that whatever number of jewelry or dresses they will provide their bride with would be their own affair because these shall eventually go to their own house. But providing the cash and the commodities in kind is a 
Folk of

must because the girl's father has got many relatives and friends to entertain while the whole village is awaiting the merry occasion to be feted. Also hiring a professional band of musicians is a must.

The head afsaqal and his opposite number bargain with each other in order to get the amount of cash and kind reduced. Sometimes, they tend to exchange unsavoury words and expression after soft pleas are not heeded.

In certain cases, these arguments become so heated that the afsaqali is postponed for scme time or cancelled altogether, the boy being engaged with another girl.

After the lafz is given and the sugar cane with its paraphernailia are taken to the boy's house, the boy's family take a step in confirming the tie by sending the material enough to make a dress for the girl, to her family. Afterwards, the boy's family makes a point of sending to the girl the material for a complete outfit consisting of her dress, pantaloons, and scarf, sometimes coupled wtih a pair of shoes, on the occasion of each "Eid" or "Barat". This is called "jora".

After engagement, the boy and girl call each other his or her "qinghal". Should the girl's mother be cooperative enough, secret rendezvous are arranged between the qinghals and this is known as "qinghal bazi". These rendezvous may take place either in the girl's house at night or in other places away from the eyes of the girl's father or brothers in the day time. The boy usually gives the girl presents of soap, scent, hair pins or needles and threads and receives gifts of boiled eggs, dried mulberries or raisins, shelled nuts, etc., tastefully packaged.

In case the girl's father or brother are fanatical and catch the boy inside their compound, they are apt to give him a good spanking and in some cases, beat the girl too. Therefore, the boys tread on this hazardous ground with extreme care and thus their mothers-in-law's cooperation is of immense importance.

WEDDING

The wedding, locally called "toy", lasts for three nights. During the first night, close relatives and friends of the couple are entertained. During the second, all the rest including relatives friedns in interning the body and sprinand neighbours are invited. During the third night henna is applied to the palms of the couple and some of their close relatives and friends and the next day, the bride is taken to her husband's house, usually on horse back, but recently in a bired car, should there be motorable roads connecting the two places.

Since marriage expenses are soaring higher and higher during the recent years, the present trend is to get over with the whole thing in a single day. Therefore a large house belonging to a rich neighbour is borrowed on the occasion with its furnishings and pots and pans refurbished from other places.

Before the wedding, the local 
barber or young boys related to the boy's family invite the guests by the word of mouth to attend the wedding which takes place at such and such man's house, at such and such time. The barber also does the cooking.

Married women usually take to the wedding between one and three of their children to have fun which immensely spoils that of others but since each woman commits the same social offense, they are not in a position to criticise one another.

Before the couple faces the mirror into which they look at each other's faces for the first time. the bride is kept in a sperate chamber, surrounded by her girl friends while a rather sophisticated woman from the village makes her up and the other young girls go on singing and dancing.

Previously, they used to powder the bride's face with pea dust in order to pluck some hair growing on some parts of he: face, Also. they used to adorn the bride's forehead with stripes of gold paper. Now these customs are on the wane, to a large extent. The bride's face is nowadays cleansed with a white stuff called "safeda" and then powdered. Her cheeks and lips are rouged. Lipsticks has also opened its way to some families in recent years. Some brides allow antimony in their eyes and others regard it as something old-fashioned.

The brides no more wear the "kamarchin" dresses these have been replaced by gold brocade gowns, satin pantaloons and the gold-thread "paizars" are substituted with modern shoes.

Despite the fact that a segregation of sexes prevails among men and women folks during the wedding as they have their separate quarters, almost everybody from the boy's as well as the girl's family take part in the merry making such as singing, dancing, etc. should they have good yorces or skill. Young girls in the women's quarters of course domuch more:

In the men's quarters, on the other hand, preferably a band from Logar or the local musicians from the nearest town entertain the guests. The band usually consists of a harmonium a pair of "tablas" or "zerbaghali" for purcussion and a "tamboor" which is a along stringed instrument. The harmonium or tamboor player usually does the ;inging tno while an amateur or professional male dancer keeps the audience speelbound.

In the men's quarters, often sums of money are paid by the guests to meet the expenses of the marriage. This is known as "shanak". A trustworthy man from the village is entrusted with this job. He usually receives each donation with a loud "thank you" and spells the amount, putting it inside a pot or something.

The women, on the other hand, pay the bride, the day after the wedding, a sum each known as "roy nomayak". While the men's donations are announced with a bang, the women keep these a bush hush. For instance, each 
woman hands the bride or mother-in-law the money inside an envelope or something which she promptly shoves under the brides mattress. Thus secrecy is based on the assumption that the woman who cannot afford to pay a large sum should. not be taunted by another who can. However, either the bride or her in-law makes a point of counting the money somehow, perhaps after each woman has left, so that her gesture should be reciprocated on a similar occasion.

While the shanak money is expended by the groom's father in meeting the marriage expenses 1ater on, the roy nomayak money is kept by the bride so that she may add on top of it something from her uwn funds and pay anuther woman in return. This exchange is known as "siali" and is a respected custom in Charikar, the provincial centre, more than other places.

Siali is actually a financial assistance rendered to friends and relatives not only in weddings but also in the case of sickness, etc. Usually, when someone visits a sick person, he or she takes along some fresh or dried fruits. Women often hand the patient or his closest relative a sum of money known as "khairat" which is returned when the doner or his closest relative falls sick. The word "siali" is also used in the context of "keeping up with the Joneses", especialiy among neighbours on weddings and so on as far as the dresses are concerned among the womenfolk.

\section{DEATH}

If some poor person dies in the village and his or her survivors cannot afford to buy the shroud or meet other expenses involved, the villagers contribute the funds. each according to his own means. They also collectively dig the gra. ve and bring the diseased on a "charpoy" carried on the shoulders of four men, each taking turns, to the common graveyard and give the survivors a hand in interning the body and sprinkling water onto the fresh grave.

Usually the concolence metting lasts for three days, either in a local mosque or in the house belonging :o the bereaved family. All this time, each sympathiser is served cups of tea. When it is lunch or dinner time, the so-called "guests" are served lavish foods according to the means of the family. Therefore, deaths, like weddings, imposo catostrphic expenses on the family, usually leading to the sale or mortgaging of part or whole property of the bereaved family.

Parwanı males similar to their countrymen living in other foothills, are not scared of death: What they want at the end of their lives is "iman", an eternal salvation. However, their womenfolk do a lot of lamenting when they lose a member of their family especially the family head. Each woman entering the room to sympathise with the wiIe or mother of the diceased puts her arms around her and shouts her head off while others follow suit. After three days of lamentation, lifs is 
normalised unless the cliceased was a man of consequence in which case each Thursday the Koran is recited by the mullahs and everybody present is fed. Same is the case with the death anniversary as well as Eids. Expressing sympathy with the bereaved family may continue through a whole year because those who were away at the time may feel guil ty withot going to the house to which they usually take someune able to recite verses from the Koran. The type of reception they may get in the house depends on the degree of their importance. If someone is too important, he is asked for lunch or dinner, as the case may be. otherwise he is only served tea.

\section{ECONOMIC PROBLEMS}

Economics in Parwan mostly revolves around farming or viniculture and therefore all problems emanate from these two sources of income.

If someone is not in a position to till his land, he has to get a tennant farmer or share-cropper. A tennant farmer usually charges between 80 and 100 seers of grain (wheat and corn) annually, plus 6 seers of ground dried mulberies known as "talkhan" and Afs. 300 in cash. On top of that, he is entitled to receive 4 seers of grain, wheat or corn, monthly.

A tennant gets one-sixth of the crop if the land-owner provides the seeds, the bullocks for ploughing and the fertilizers which are

a must in recent years.

Should the owner provide only the seeds, he receives two-thirds of the crops. Otherwise only with his land, he gets half of it.

If somebody makes available his land to someone in order to grow vines, he is entitled to three fifths of the vines after they come to fruition. Of course the landowner has the right to choose any part he may like, providing that his option does not affect the fair division. For instance, he can say he accepts the vines grown in the north, or south, east or west of the vinyard. This method makes the vine grower raise all the vines with equal care.

If the owner of a vinyard is unable to take care of his property, he gives it to someone else to look after. This man is responsible for spading, irrigating, pruning and covering the vines (in late autumn) as well as safety against thieves and is entitled to get onefifth or one-sixth of grapes, raisins or the income therefrom.

In case a man reases a pieace of land or a vinyard and the crop is damaged by a natural disaster such as a terrible hail-storm or drought, the man may approach the owner to reduce the amount of lease. The owner may argue:

"Did you share with me your extra revenues last year that you are now asking for a reduction?"

However, with good offices on the part of one or two village eldermen, the matter is settled equitably.

\section{BUSINESS}

Almost in each village, there is one shop to meet the daily requ- 
Irements of the villagers. However, the villagers are fond of going io the bazaar, at least once a week, not only to buy their things cheaper but also to meet their friends from. other villages. who also descend on the shops. These bazaars are actually weekly fairs whose dates differ from one place to another. For instance, in Qara Bagh, the bazaar day is Monday, in Ghulam Ali on Sunday and in Deh Bali it is Friday. Villagers bring their things for sale to one of these bazaars and buy what they need.

During the other days, a number of persons who are actually mounted peddlars supply the housewives with their petty requirements and some times also sell meat and charge either in cash or kind, the latter usually in the form of wheat, corn or raisins. The village shops do the same but at lower rates of exchange.

\section{PROVERBS AND DOBAITIS}

Proverbs used in Parwan are not much different from those current in other Dari-speaking provinces. Of course there is a number of different words and slangs in Parwan which may not be understandable to the people of other provinces. These are. for instance, "tashalluk" which means "personal greed" or "tajan'.- meaning "hurry".

However, Parwanis use special dobaitis which are locally called charbaitis. But unfortunately now charbaitis, some of them composed by contemporary poets. have penetrated into the main bo- dy of foik litersiure, adultrat. ing it. Now it is difficult to sift them and keep only the orginals.

But the different ways the char. baitis sung by Parwanis are easily distinguishable and when someons sings then $r, j$ th or without musc. almost everybody of sound ear and mind knows whe. ther it is Saighani or Kahmardi. Ghorband or Tashqurghani, each having its own flavour and beauty.

\section{SUPERSTITIONS}

Superstitions in Parwan are not much different from those prevalent elsewhere. For instance, the women folk still believe in witchcraft and magic. If a baby falls sick, the mother approaches the man who scribbles a talisman and pays him some fee with which otherwise she could very well buy her child the necessary medicine. In most cases, the baby is taken to the doctor when nothing is left of him.

Fear of evil spirits and "jins" is still prevalent among women and children. Usually an $o^{\prime} d$ man basking in the sunshine from late autumn till next spring spins yarns to keep the village boys spell-bound. He tells them stories about "Almasti", "Mard Azmay". "Madare Al" and the "Black Cat". Children grow up with these images and consequent fears in their minds unless these are erazed by a sound education through schooling.

Almasti is supposedly a married woman who has not taken the prescribed bath after each sexual intercourse with her hus- 
band. As a punishment, her eyes have four slits instead of the usual two, two horizontal and others vertical A foul odour exudes from her body and dress. On seeing her, everybody faints and she rips ber victim's belly open and eats up his liver. She is supposedly fond of roasting the livers of younger children.

Mard Azmai is supposedly a terribly tall fellow who comes across one at odd hours and disappears when one touches one's trousers' belt or band, otherwise ono is bound to faint and even die out of fear.

The Black Cat is the ordinary alley cat which is supposed to be a member of a jin family staying with a family of humans for espionage purposes. It keeps an eye on the family to find out who they entertain, what sort of relationships exist between the husband and his wife, what the family eats and how it treats animals. On Thursday nights when all the jins are free to do what they want, the Black Cat disappears mysteriously to entertain its own folks

But the supposed effect of jins on women tops all the superstitions in Parwan. A woman suddenly collapses on the floor with a pale complexion, stiff limbs and a foaming mouth from time to time, or on special occasions. She may express strange and incoherent things, even in a different language, or beat up herself or those nearest to her. For instance. she may say, in a nutshell, that her body is chosen as an abodo for the ash-coloured jins and is tormented by them because she once trampled to death one of their children under a rose bush.

In order to cure this disease which should be a type of hysteria, a mullah or a iin extraction specialist is summoned. Should the woman feign this in order to get something from her husband, the man advises her to stop it and he will ask her husband to buy her a new dress for the next wedding in the village. In case the woman persists, the man puts wood scrapements between her fingers and squeezes them so hard that she starts screaming and then tells the man should her husband have the Koran recited in the house, the jins will $a b$. andon their abode.

Generally speaking folkways in Parwan are numerous and varied in the foothills but the people in the plains are influenced by the so-called city culture which is increasingly affected by outside influences.

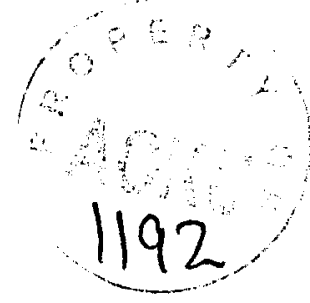

